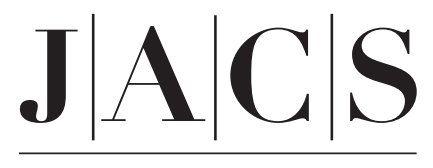

A R T I C L E S

Published on Web 04/17/2002

\title{
Bifunctional Pincer-type Organometallics as Substrates for Organic Transformations and as Novel Building Blocks for Polymetallic Materials
}

\author{
Gema Rodríguez, ${ }^{\dagger}$ Martin Albrecht, ${ }^{\dagger}$ Jeroen Schoenmaker,${ }^{\dagger}$ Alan Ford, ${ }^{\dagger}$

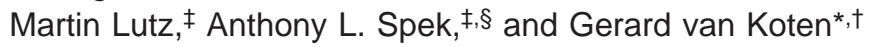 \\ Contribution from the Department of Metal-Mediated Synthesis, Debye Institute, and Department \\ of Crystal and Structural Chemistry, Bijvoet Center for Biomolecular Research, Utrecht \\ University, Padualaan 8, 3584 CH Utrecht, The Netherlands
}

Received December 14, 2001

\begin{abstract}
The reactivity of the bifunctionalized ligand $\mathrm{NC}(\mathrm{Br}) \mathrm{N}-\mathrm{I} 1\left[\mathrm{IC}_{6} \mathrm{H}_{2}\left(\mathrm{CH}_{2} \mathrm{NMe}_{2}\right)_{2}-3,5-\mathrm{Br}-4\right]$ has been studied as a versatile synthon for organic and/or organometallic synthesis. Chemoselective metalation (M $=\mathrm{Pd}, \mathrm{Pt}, \mathrm{Li})$ at the $\mathrm{C}_{\text {aryl}}-\mathrm{I}$ or $\mathrm{C}_{\text {aryl }}-\mathrm{Br}$ bonds was achieved by choosing the appropriate metal precursors. In this way a series of $\mathrm{Pt}^{\prime \prime}$ and $\mathrm{Pd}$ " complexes were prepared that have a second functional group available for further reactions. These Pt" and PdII complexes were subjected to a wide range of organic and organometallic reactions, revealing the remarkable stability of their $\mathrm{M}-\mathrm{C} \sigma$-bond and opening an easy route for the synthesis of mono- and (hetero)bimetallic building blocks. The scope of the chemistry of such building blocks shows that they are good candidates for use in the synthesis of dendrimers, bioorganometallic systems, or polymetallic materials. The X-ray crystal structures of the most representative complexes (2, 3a, 19, 20, and 24) are also reported.
\end{abstract}

\section{Introduction}

Organometallic complexes are excellent functional units in macroscopic devices, e.g., for application in catalysis ${ }^{1}$ and sensing. ${ }^{2}$ Usually the introduction of the active site (the transition metal) is the last step of the synthetic protocol of such systems since the organometallic center is considered to be the most labile and sensitive part of the device. A drawback of this strategy is the often tedious separation of unreacted ligands and metal residues due to incomplete metalation. Alternative strategies that are based on metalated building blocks would circumvent this issue. This new approach requires the availability of bifunctional ligands that can be selectively metalated at one position only. This should provide stable organometallic building blocks containing a second functional group for further syntheses.

A suitable methodology to stabilize the $\mathrm{M}-\mathrm{C}$ bond involves the principles of chelation, i.e. the formation of complexes containing an $\mathrm{M}-\mathrm{C}$ bond that is supported by intramolecular (heteroatom) coordination to the metal center. ${ }^{3}$ By use of this

* Corresponding author: Phone +31-30-2533120; fax +31-30-2523615; e-mail g.vankoten@chem.uu.nl.

Department of Metal-Mediated Synthesis, Debye Institute.

$\doteqdot$ Department of Crystal and Structural Chemistry, Bijvoet Center for Biomolecular Research.

$\S$ Corresponding author for crystallographic data: Phone +31-302532538; fax +31-30-2523940; e-mail a.l.spek@chem.uu.nl.

(1) (a) Halpern, J. Pure Appl. Chem. 2001, 73, 209-220. (b) Loch, J. A.; Crabtree, R. H. Pure Appl. Chem. 2001, 73, 119-128. (c) Thomas, J. M. Angew. Chem. 1999, 113, 3801-3843; Angew. Chem., Int. Ed. 1999, 38 , 3588-3628. (d) Zamaraev, K. Pure Appl. Chem. 1997, 69, 865-876.

(2) See, for example, Beer, P. D.; Gale, P. A. Angew. Chem. 2001, 113, 502532; Angew. Chem., Int. Ed. 2001, 40, 486-516. methodology, various complexes have been obtained that display a high thermal stability paired with a high or unprecedented catalytic activity. ${ }^{4}$ Our work in this field has concentrated on transition-metal complexes containing terdentate monoanionic pincer ligands $\left[\mathrm{C}_{6} \mathrm{H}_{3}\left\{\mathrm{CH}_{2} \mathrm{NMe}_{2}\right\}_{2}-2,6-\mathrm{R}\right]^{-}$, in particular those that bond in the $\eta^{3}$-mer-N,C,N coordination mode (Chart 1). ${ }^{5}$

In the course of these studies, various useful applications have been identified in the fields of catalysis, ${ }^{6}$ sensors, ${ }^{7}$ and the construction of switches. ${ }^{8}$ Therefore, we decided to study the reactivity of the bifunctional ligand $\mathrm{NC}(\mathrm{Br}) \mathrm{N}-\mathrm{I} 1$ [NC(Br)N-I is the abbreviation for $\mathrm{IC}_{6} \mathrm{H}_{2}\left(\mathrm{CH}_{2} \mathrm{NMe}_{2}\right)_{2}-3,5-\mathrm{Br}-4$, Chart 1] for (transition) metal complexation. In this ligand a $\mathrm{C}_{\text {aryl }}-\mathrm{Br}$ bond

(3) Dehand, J.; Pfeffer, M. Coord. Chem. Rev. 1976, 18, 327-352.

(4) (a) Liu, F.; Pak, E. B.; Singh, B.; Jensen, C. M.; Goldman, A. S. J. Am. Chem. Soc. 1999, 121, 4086-4087. (b) Liou, S.-Y.; van der Boom, M. E. Milstein, D. Chem. Commun. 1998, 687-688. (c) Herrmann, W. A.; Brossmer, C.; Reisinger, C.-P.; Riermeier, T. H.; Ofele, K.; Beller, M. Chem. Eur. J. 1997, 3, 1357-1364. (d) Gupta, M.; Hagen, C.; Kaska, W. C.; Cramer, R. E.; Jensen, C. M. J. Am. Chem. Soc. 1997, 119, 840-841. (e) Moulton, C. J.; Shaw, B. L. J. Chem. Soc., Dalton Trans. 1976, 10201024

(5) (a) Albrecht, M.; van Koten, G. Angew. Chem. 2001, 113, 3866-3898; Angew. Chem., Int. Ed. 2001, 40, 3750-3781. (b) Rietveld, M. H. P.; Grove, D. M.; van Koten, G. New J. Chem. 1997, 21, 751-771. (c) van Koten, G. Pure Appl. Chem. 1989, 61, 1681-1694.

(6) See, for example, (a) Rodríguez, G.; Lutz, M.; Spek, A. L.; van Koten, G. Chem. Eur. J. 2002, 8, 45-57. (b) Dani, P.; Karlen, T.; Gossage, R. A.; Gladiali, S.; van Koten, G. Angew. Chem. 2000, 112, 759-761; Angew. Chem., Int. Ed. 2000, 39, 743-745. (c) Beletskaya, I. P.; Chuchurjukin, A. V.; Dijkstra, H. P.; van Klink, G. P. M.; van Koten, G.; Tetrahedron Lett. 2000, 41, 1075-1079. (d) Grove, D. M.; van Koten, G.; Verschuuren A. H. M. J. Mol. Catal. 1988, 45, 169-174.

(7) See, for example, (a) Albrecht, M.; Gossage, R. A.; Lutz, M.; Spek, A. L.; van Koten, G. Chem. Eur. J. 2000, 6, 1431-1445. (b) Albrecht, M.; van Koten, G. Adv. Mater. 1999, 171-174.

(8) See, for example, (a) Albrecht, M.; Lutz, M.; Spek, A. L.; van Koten, G. Nature 2000, 406, 970-974. (b) Steenwinkel, P.; Grove, D. M.; Veldman, N.; Spek, A. L.; van Koten, G. Organometallics 1998, 17, 5647-5655. 
Chart 1. $\eta^{3}-\mathrm{N}, \mathrm{C}, \mathrm{N}-$ Bonded NCN-R Pincer Ligand in a

$\mathrm{MX}_{n}(\mathrm{NCN}-\mathrm{R}) \mathrm{L}_{m}$ Complex and the Bifunctional Ligand 1 That Can Be Selectively Metalated<smiles>[R]c1ccc2c(c1[R])CN(C)CN2C</smiles><smiles>CN(C)Cc1cc(I)cc(CN(C)C)c1Br</smiles>

$\left[M X_{n}(N C N-R) L_{m}\right]$

1

Scheme 1. Chemoselective Metalation of the Bifunctional NCN Ligand $1^{a}$

Route B

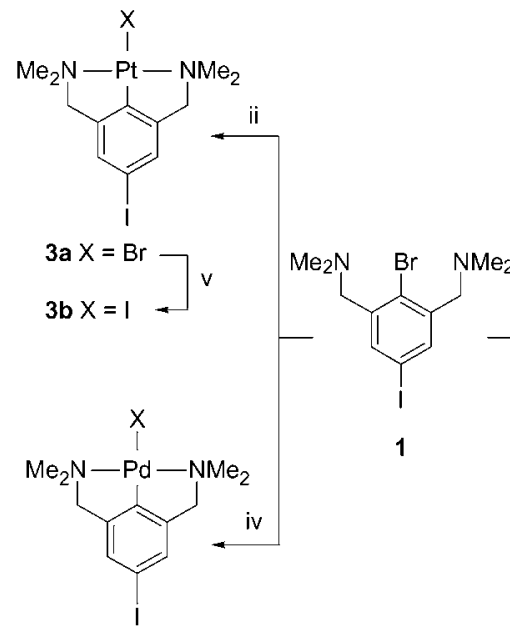

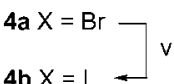

${ }^{a}$ Reagents and conditions: (i) $\left[\mathrm{Pt}\left(\mathrm{PPh}_{3}\right)_{4}\right]$, toluene, $\Delta, 20 \mathrm{~h}$. (ii) $[\mathrm{Pt}$ tol4) $\left.{ }_{2}\left(\mathrm{SEt}_{2}\right)\right]_{2}$, benzene, $\Delta, 2 \mathrm{~h}$. (iii) $\left[\mathrm{Pd}\left(\mathrm{PPh}_{3}\right)_{4}\right]$, toluene, $50{ }^{\circ} \mathrm{C}, 1 \mathrm{~d}$. (iv) $\left[\mathrm{Pd}_{2}(\mathrm{dba})_{3} \cdot \mathrm{CHCl}_{3}\right]$, toluene, $-80{ }^{\circ} \mathrm{C} \rightarrow \mathrm{RT}$. (v) (a) $\mathrm{AgBF}_{4}$, acetone/ $\mathrm{CH}_{2} \mathrm{Cl}_{2}$ (1:1), RT, $30 \mathrm{~min}$; (b) NaI, acetone, RT, $3 \mathrm{~h}$.

and a more reactive $\mathrm{C}_{\text {aryl }}-\mathrm{I}$ bond are available for oxidative addition or metal-halide exchange. Importantly, the two orthochelating amine groups may support metalation but only at the former position. Variation of metal precursor and reaction conditions may therefore lead to chemoselective metalation, since either kinetic (viz., the higher reactivity of the $\mathrm{C}_{\text {aryl }}-\mathrm{I}$ bond) or thermodynamic arguments (viz., stability through chelation) may dominate the outcome of the reaction. We report on the selective preparation of these organometallic systems and the scope and limitation of the resulting complexes as substrates in subsequent organic and metal-mediated reactions. Furthermore, these studies provided access to new strategies for the preparation of multimetallic materials such as peripheryfunctionalized dendritic ${ }^{9}$ structures and polymers. ${ }^{10}$

\section{Results and Discussion}

Chemoselective Metalation of 1. Refluxing of equimolar amounts of $\mathbf{1}$ and $\left[\mathrm{Pt}\left(\mathrm{PPh}_{3}\right)_{4}\right]$ in toluene for $20 \mathrm{~h}$ afforded selectively the oxidative addition product 2 (Scheme 1 ). ${ }^{11}$ The aromatic protons of $\mathbf{2}$ provide a diagnostic probe for the site of

(9) See, for example, (a) Kreiter, R.; Kleij, A. W.; Klein Gebbink, R. J. M.; van Koten, G. Top. Curr. Chem. 2001, 217, 163-199. (b) Newkome, G R.; He, E.; Moorefield, C. N. Chem. Rev. 1999, 99, 1689-1746.

(10) See, for example, Manners, I. Angew. Chem. 1996, 108, 1712-1731; Angew. Chem., Int. Ed. Engl. 1996, 35, 1602-1621.

(11) Manna, J.; Whiteford, J. A.; Stang, P. J. J. Am. Chem. Soc. 1996, 118, $8731-8732$
Table 1. Selected ${ }^{1} \mathrm{H}$ NMR and ${ }^{31} \mathrm{P}$ NMR Data ${ }^{a}$

\begin{tabular}{|c|c|c|c|c|c|}
\hline complex & $\mathrm{C}_{\text {aryl- }} \mathrm{H}^{b}\left({ }^{3} \mathrm{~J}_{\mathrm{H}, \mathrm{Pt}}\right)$ & $\mathrm{ArCH}_{2} \mathrm{~N}\left({ }^{3} \mathrm{~J}_{\mathrm{H}, \mathrm{Pt}}\right)$ & $\mathrm{NCH}_{3}\left({ }^{3} J_{\mathrm{H}, \mathrm{Pt}}\right)$ & aryl- $\mathrm{H}^{c}$ & $\delta_{\mathrm{P}}\left({ }^{1} J_{\mathrm{P}, \mathrm{Pt}}\right)$ \\
\hline 1 & 7.68 & 3.48 & 2.30 & & \\
\hline 2 & $6.71(57.3)$ & 2.88 & 1.99 & $\begin{array}{l}7.59-7.53(\mathrm{~m}) \\
7.33-7.23(\mathrm{~m})\end{array}$ & $21.1(3030.2)$ \\
\hline 3a & 7.14 & $3.97(46.2)$ & $3.10(38.0)$ & & \\
\hline $3 \mathbf{b}$ & 7.15 & $3.98(46.8)$ & $3.17(38.0)$ & & \\
\hline $\mathbf{4 a}^{d}$ & 6.80 & 2.99 & 2.48 & & \\
\hline $\mathbf{4} \mathbf{b}^{d}$ & 6.80 & 2.99 & 2.51 & & \\
\hline $\mathbf{5}^{e}$ & 6.65 & 2.86 & 1.91 & $\begin{array}{l}7.55-7.48(\mathrm{~m}) \\
7.39-7.34(\mathrm{~m}) \\
7.30-7.25(\mathrm{~m})\end{array}$ & $23.7^{d}$ \\
\hline 19 & 6.81 & 3.41 & 1.80 & $\begin{array}{l}7.97(\mathrm{br}) \\
7.35(\mathrm{br}) \\
6.41(\mathrm{br})\end{array}$ & 16.9 (2988.6) \\
\hline 20 & $6.13(57.4)$ & $3.30(44.0)$ & $2.98(37.0)$ & $\begin{array}{l}7.71-7.55(\mathrm{~m}) \\
7.36-7.16(\mathrm{~m})\end{array}$ & $22.3(3091.6)$ \\
\hline 21 & 6.05 & $3.31(45.8)$ & $2.99(39.2)$ & $\begin{array}{l}7.75-7.62(\mathrm{~m}) \\
7.57-7.44(\mathrm{~m}) \\
7.42-7.24(\mathrm{~m})\end{array}$ & $23.4^{d}$ \\
\hline 22 & $6.10(56.1)$ & 3.26 & 2.81 & $\begin{array}{l}7.60-7.51(\mathrm{~m}) \\
7.40-7.26(\mathrm{~m})\end{array}$ & $22.5(3071.7)$ \\
\hline 23 & 6.06 & 3.29 & 2.79 & $\begin{array}{l}7.57-7.44(\mathrm{~m}) \\
7.40-7.28(\mathrm{~m})\end{array}$ & 25.9 \\
\hline
\end{tabular}

${ }^{a}$ Singlet signals from $\mathrm{CDCl}_{3}$ solutions unless otherwise stated; $\delta$ values are given in parts per million, and $J$ values are given in hertz. ${ }^{b}$ In pincer skeleton. ${ }^{c}$ Of $\mathrm{PPh}_{3} .{ }^{d}$ In $\mathrm{C}_{6} \mathrm{D}_{6} .{ }^{e}$ In $\mathrm{CD}_{2} \mathrm{Cl}_{2}$.
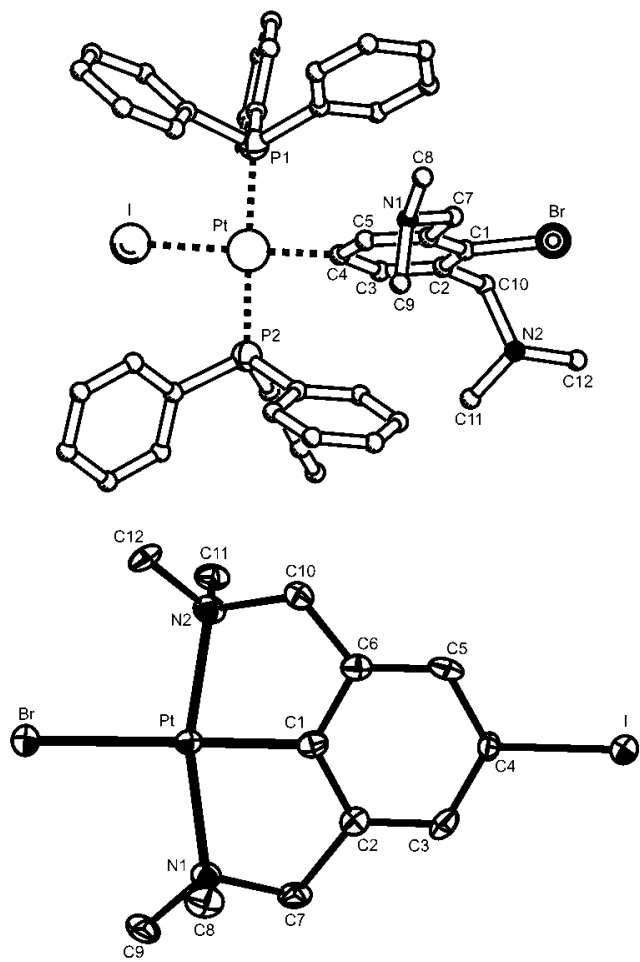

(b)

Figure 1. Molecular plots of compounds (a) 2 and (b) 3a. The pincer ligand in $\mathbf{2}$ is disordered and it was therefore partially refined with isotropic displacement parameters. Only the major disorder component is displayed here. The $\mathrm{CH}_{2} \mathrm{Cl}_{2}$ solvent molecule in $\mathbf{2}$ and hydrogen atoms in both structures have been omitted for clarity.

platination, since they appear in the ${ }^{1} \mathrm{H}$ NMR spectrum as a high-field singlet with satellites due to ${ }^{195} \mathrm{Pt}-{ }^{1} \mathrm{H}$ couplings $\left(\delta_{\mathrm{H}}\right.$ $\left.=6.71,{ }^{3} J_{\mathrm{H}, \mathrm{Pt}}=57.3 \mathrm{~Hz}\right)($ Table 1$)$.

Unequivocal confirmation of the proposed connectivity pattern was obtained from a single-crystal structure determination of 2. The molecular structure is shown in Figure 1a and relevant bond distances and angles are summarized in Table 2.

The overall structural features of $\mathbf{2}$ are similar to those of related platinum complexes. ${ }^{12}$ The metal square-plane is slightly 
Table 2. Selected Bond Lengths and Bond and Torsion Angles of Complexes 2, 3a, 19, 20, and 24

\begin{tabular}{|c|c|c|c|}
\hline \multicolumn{2}{|c|}{ bond lengths $(\AA)$} & \multicolumn{2}{|c|}{ bond angles (deg) } \\
\hline & & & $\operatorname{lex} 2$ \\
\hline $\mathrm{Pt}-\mathrm{I}$ & $2.6944(4)$ & $\mathrm{P} 1-\mathrm{Pt}-\mathrm{P} 2$ & $176.95(4)$ \\
\hline $\mathrm{Pt}-\mathrm{C} 41$ & $2.021(6)$ & $\mathrm{I}-\mathrm{Pt}-\mathrm{C} 41$ & $171.9(3)$ \\
\hline $\mathrm{Pt}-\mathrm{P} 1$ & $2.3087(10)$ & $\mathrm{I}-\mathrm{Pt}-\mathrm{P} 1$ & $88.64(3)$ \\
\hline $\mathrm{Pt}-\mathrm{P} 2$ & $2.3068(11)$ & $\mathrm{I}-\mathrm{Pt}-\mathrm{P} 2$ & $93.99(3)$ \\
\hline
\end{tabular}

\begin{tabular}{|c|c|}
\hline torsion a & \\
\hline $\begin{array}{l}\mathrm{Pt}-\mathrm{C} 41-\mathrm{C} 51-\mathrm{C} 61 \\
\mathrm{C} 21-\mathrm{C} 31-\mathrm{C} 41-\mathrm{Pt} \\
\mathrm{P} 1-\mathrm{Pt}-\mathrm{C} 41-\mathrm{C} 31 \\
\mathrm{P} 1-\mathrm{Pt}-\mathrm{C} 41-\mathrm{C} 51 \\
\mathrm{P} 2-\mathrm{Pt}-\mathrm{C} 41-\mathrm{C} 31 \\
\mathrm{P} 2-\mathrm{Pt}-\mathrm{C} 41-\mathrm{C} 51\end{array}$ & $\begin{array}{r}-173.7(4) \\
172.4(3) \\
-101.8(3) \\
74.6(4) \\
80.1(3) \\
-103.6(4)\end{array}$ \\
\hline $\begin{array}{l}\mathrm{Pt}-\mathrm{C} 1-\mathrm{C} 2-\mathrm{C} 3 \\
\mathrm{Pt}-\mathrm{C} 1-\mathrm{C} 6-\mathrm{C} 5 \\
\mathrm{C} 1-\mathrm{C} 2-\mathrm{C} 7-\mathrm{N} 1 \\
\mathrm{C} 1-\mathrm{C} 6-\mathrm{C} 10-\mathrm{N} 2\end{array}$ & $\begin{array}{c}-178.6(7) \\
178.7(7) \\
-24.9(12) \\
-23.6(12)\end{array}$ \\
\hline $\begin{array}{l}\mathrm{Pt}-\mathrm{C} 1-\mathrm{C} 2-\mathrm{C} 3 \\
\mathrm{Pt}-\mathrm{C} 1-\mathrm{C} 6-\mathrm{C} 5 \\
\mathrm{P} 1-\mathrm{Pt}-\mathrm{C} 1-\mathrm{C} 2 \\
\mathrm{P} 1-\mathrm{Pt}-\mathrm{C} 1-\mathrm{C} 6 \\
\mathrm{P} 2-\mathrm{Pt}-\mathrm{C} 1-\mathrm{C} 2 \\
\mathrm{P} 2-\mathrm{Pt}-\mathrm{C} 1-\mathrm{C} 6\end{array}$ & $\begin{array}{r}175.9(2) \\
-176.1(2) \\
92.2(2) \\
-90.1(3) \\
-85.6(2) \\
92.1(3)\end{array}$ \\
\hline $\begin{array}{l}\mathrm{Pt} 1-\mathrm{C} 1-\mathrm{C} 2-\mathrm{C} 3 \\
\mathrm{Pt} 1-\mathrm{C} 1-\mathrm{C} 6-\mathrm{C} 5 \\
\mathrm{C} 1-\mathrm{C} 6-\mathrm{C} 7-\mathrm{N} 2 \\
\mathrm{C} 1-\mathrm{C} 2-\mathrm{C} 9-\mathrm{N} 1 \\
\mathrm{P} 1-\mathrm{Pt} 2-\mathrm{C} 4-\mathrm{C} 5 \\
\mathrm{P} 1-\mathrm{Pt} 2-\mathrm{C} 4-\mathrm{C} 3\end{array}$ & $\begin{array}{c}180.01 \\
180.01 \\
32.0(5) \\
42.4(5) \\
84.52(3) \\
-95.48(3)\end{array}$ \\
\hline $\begin{array}{l}\mathrm{Pt}-\mathrm{C} 1-\mathrm{C} 2-\mathrm{C} 3 \\
\mathrm{Pt}-\mathrm{C} 1-\mathrm{C} 6-\mathrm{C} 5 \\
\mathrm{C} 1-\mathrm{C} 2-\mathrm{C} 7-\mathrm{N} 1 \\
\mathrm{C} 1-\mathrm{C} 6-\mathrm{C} 10-\mathrm{N} 2\end{array}$ & $\begin{array}{r}-179.3(5) \\
177.9(5) \\
21.9(7) \\
24.4(8)\end{array}$ \\
\hline
\end{tabular}

distorted and includes trans-positioned phosphine groups [P1$\mathrm{Pt}-\mathrm{P} 2$ and $\mathrm{C} 41-\mathrm{Pt}-\mathrm{I}$ are $176.95(4)^{\circ}$ and $171.9(3)^{\circ}$, respectively]. The aromatic ring of the monodentate pincer ligand has nearly perpendicular orientation to the metal coordination plane [torsion angle $\mathrm{P} 1-\mathrm{Pt}-\mathrm{C} 41-\mathrm{C} 31$ is $-101.8(3)^{\circ}$ ]. The metalcarbon bond $[\mathrm{Pt}-\mathrm{C} 412.021(6) \AA]$ is significantly longer than in complexes where this bond is supported by chelating phosphine or nitrogen donors (typically 1.90-1.95 $\AA$, vide infra). Because of the absence of the chelating coordination, the pincer ligand is disordered in the crystal.

Chemoselective platinum insertion into the $\mathrm{C}-\mathrm{Br}$ bond of $\mathbf{1}$ and formation of complex $\mathbf{3 a}$ (Scheme 1) was performed following a method recently described by Canty et al. ${ }^{13}$ The reaction of a benzene solution of $\mathbf{1}$ with a stoichiometric amount of the metal precursor $\left[\mathrm{Pt}(\mathrm{tol}-4)_{2}\left(\mathrm{SEt}_{2}\right)\right]_{2}$ afforded complex $\mathbf{3 a}$ within 2 h. To unambiguously establish the proposed structure and hence the selectivity of the platination reaction a singlecrystal structure determination of $\mathbf{3 a}$ was performed (Figure 1b, relevant bond distances and angles in Table 1).

The molecular structure of $\mathbf{3} \mathbf{a}$ shows a $\mathrm{Pt}^{\mathrm{II}}$ center in a distorted square-planar environment and embedded in the coordination pocket of the terdentate N,C,N framework of the pincer ligand, which is in agreement with other similar, earlier reported, $\mathrm{Pt}^{\mathrm{II}}$ complexes. ${ }^{14}$ A short $\mathrm{Pt}-\mathrm{C} \sigma$-bond $[\mathrm{Pt}-\mathrm{C} 1$ 1.927(8) $\AA$ ] due to rigid chelation of the amine groups is noted.

(12) Manna, J.; Kuehl, C. J.; Whiteford, J. A.; Stang, P. J. Organometallics 1997, 16, 1897-1905

(13) Canty, A. J.; Patel, J.; Skelton, B. W.; White, A. H. J. Organomet. Chem. 2000, 599, 195-199.
The present results suggest that coordination of one or both amine substituents in $\mathbf{1}$ to the platinum center in the metal precursor $\left[\mathrm{Pt}(\text { tol-4 })_{2}\left(\mathrm{SEt}_{2}\right)\right]_{2}$ must be a key interaction during the formation of $\mathbf{3 a}$, which leads to attack of the $\mathrm{C}_{\text {aryl }}-\mathrm{Br}$ and not the $\mathrm{C}_{\text {aryl }}-\mathrm{I}$ bond.

Interestingly, palladation of $\mathbf{1}$ with $\left[\mathrm{Pd}_{2}(\mathrm{dba})_{3} \cdot \mathrm{CHCl}_{3}\right]$ as the metal precursor required low temperatures $\left(-80{ }^{\circ} \mathrm{C}\right.$, toluene solution) and again occurs selectively into the $\mathrm{C}_{\text {aryl }}-\mathrm{Br}$ bond, affording pure complex $\mathbf{4 a}$ as a yellowish solid (Scheme 1). The organopalladium complex $\mathbf{4 a}$ contains the pincer ligand in the well-established N,C,N-terdentate bonding mode, which was established by comparison of the spectroscopic data of $\mathbf{4 a}$ with those of related complexes. ${ }^{14 \mathrm{~b}, 15}$

Opposite results were obtained with palladium $(0)$ precursors containing phosphine ligands. Treatment of a toluene solution of 1 with $\left[\mathrm{Pd}\left(\mathrm{PPh}_{3}\right)_{4}\right]$ at $50{ }^{\circ} \mathrm{C}$ for 1 day induced the oxidative addition of the palladium( $(0)$ precursor to 1 via selective $\mathrm{C}_{\text {aryl }}-\mathrm{I}$ bond activation and complex $\mathbf{5}$ was isolated as the single product (Scheme 1). Assignment of the structure of $\mathbf{5}$ was done on the basis of spectroscopic data, which are in agreement with those obtained for $\mathbf{2}$ (Table 1) and for related palladium(II) complexes containing a NCN pincer ligand without a bromide substituent. ${ }^{16}$

(14) (a) Terheijden, J.; van Koten, G.; Muller, F.; Grove, D. M.; Vrieze, K Nielsen, E.; Stam, C. H. J. Organomet. Chem. 1986, 315, 401-417. (b) van Koten, G.; Timmer, K.; Noltes, J. G.; Spek, A. L. J. Chem. Soc., Chem. Commun. 1978, 250-252.

(15) Alsters, P. L.; Baesjou, P. J.; Janssen, M. D.; Kooijman, H.; SichererRoetman, A.; Spek, A. L.; van Koten, G. Organometallics 1992, 11, 41244135.

(16) Spee, M. P. R.; Ader, B.; Steenwinkel, P.; Kooijman, H.; Spek, A. L.; van Koten, G. J. Organomet. Chem. 2000, 598, 24-27. 
Scheme 2. Chemoselective Lithiation of the Bifunctional NCN Ligand $\mathbf{1}^{a}$

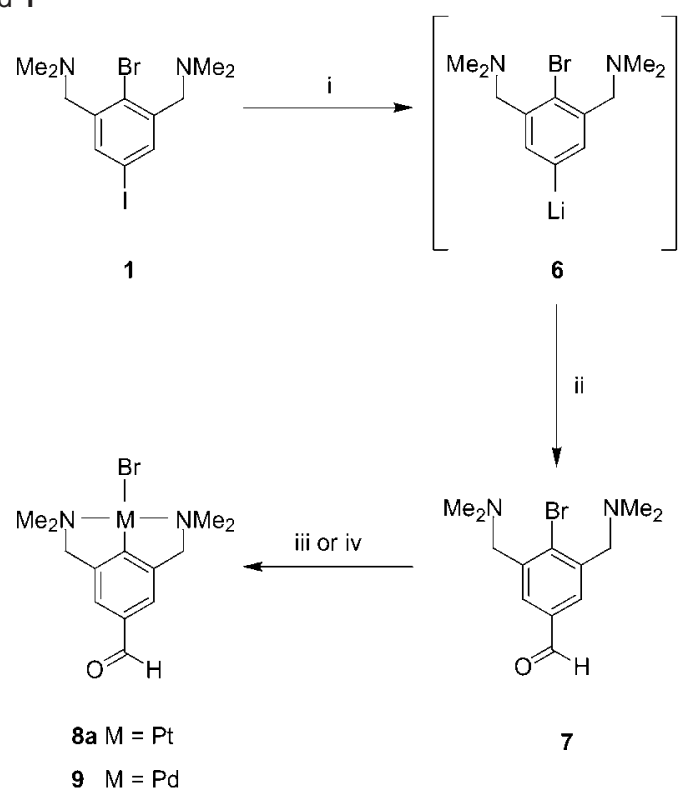

${ }^{a}$ Reagents and conditions: (i) $t-\mathrm{BuLi}, \mathrm{Et}_{2} \mathrm{O},-100{ }^{\circ} \mathrm{C}$. (ii) DMF. (iii) $\left[\mathrm{Pt}(\text { tol-4) })_{2}\left(\mathrm{SEt}_{2}\right)\right]_{2}$, benzene, $\Delta, 2 \mathrm{~h}$. (iv) $\left[\mathrm{Pd}(\mathrm{dba})_{2} \cdot \mathrm{CHCl}_{3}\right]$, toluene, -80 ${ }^{\circ} \mathrm{C} \rightarrow \mathrm{RT}$.

Strict temperature control of this reaction appeared to be essential, since at lower temperatures $\left(25^{\circ} \mathrm{C}\right)$ only starting material was recovered, whereas at more elevated temperatures $\left(80{ }^{\circ} \mathrm{C}\right)$ other metalated products were obtained that could not be identified.

Hence, reaction conditions have been established that promote oxidative addition of a palladium or platinum precursor selectively to either the $\mathrm{C}_{\text {aryl }}-\mathrm{I}$ bond (route $\mathrm{A}$, Scheme 1) or the $\mathrm{C}_{\text {aryl }}-\mathrm{Br}$ bond (route $\mathrm{B}$, Scheme 1), leaving the other carbonhalide bond of the ligand precursor unaffected. This chemoselectivity is remarkable, since it is well-known that oxidative addition of transition metals to aryl halides follows the order ArI $>$ ArBr $\gg$ ArCl. ${ }^{17}$ Oxidative addition of $\left[\mathrm{M}\left(\mathrm{PPh}_{3}\right)_{4}\right]$ to 1 (i.e., route $\mathrm{A}$ ) proceeds according to this reactivity sequence and obviously is kinetically controlled, whereas the opposite selectivity is observed when the phosphine-free compounds [Pt(tol-4) $\left.)_{2}\left(\mathrm{SEt}_{2}\right)\right]_{2}$ and $\left[\mathrm{Pd}_{2}(\mathrm{dba})_{3} \cdot \mathrm{CHCl}_{3}\right]$ are used as metal precursors (route $\mathrm{B}$ ), and therefore the thermodynamic products $\mathbf{3 a}$ and 4 were obtained. ${ }^{18}$ In route $\mathrm{B}$, prior coordination of the nitrogen donor atoms of $\mathbf{1}$ to the metal center can occur since the metal precursor lacks strongly bound ligands. This directs the addition of the metal to the $\mathrm{C}_{\text {aryl }}-\mathrm{Br}$ bond, which as a consequence leaves the $\mathrm{C}-\mathrm{I}$ bond unaffected. Apparently when $\left[\mathrm{M}\left(\mathrm{PPh}_{3}\right)_{4}\right]$ is used, phosphine coordination to platinum or palladium reduces the relevance of the nitrogen donors of $\mathbf{1}$ significantly since the $\mathrm{M}-\mathrm{P}$ bond is considerably stronger than the corresponding $\mathrm{M}-\mathrm{N}$ bond. Consequently the more reactive $\mathrm{C}-\mathrm{I}$ bond is preferentially cleaved. ${ }^{16}$ In either case, a reactive $\mathrm{C}-\mathrm{X}$ bond $(\mathrm{X}=\mathrm{Br}$ in $\mathbf{2}$ and $\mathbf{5}, \mathrm{X}=\mathrm{I}$ in $\mathbf{3 a}$ and $\mathbf{4 a})$ remains available for further functionalization.

(17) Collman, J. P.; Hegedus, L. S.; Norton, J. R.; Finke, R. G. Principles and Applications of Organotransition Metal Chemistry; University Science Books: Mill Valley, CA, 1987.

(18) Although no oxidative addition of $\left[\mathrm{Pd}_{2}(\mathrm{dba})_{3} \cdot \mathrm{CHCl}_{3}\right]$ to the $\mathrm{C}_{\text {aryl }}-\mathrm{I}$ bond of 1 has been observed, it cannot be excluded with the present data. However, if such a hypothetical complex would indeed be formed, it is, in contrast to the characterized complex $\mathbf{4}$, apparently not stable enough and reductive elimination takes place, affording the starting materials again.
Scheme 3. Pincer-Pt" Complexes for Organic Transformations<smiles>[R]C(=O)Oc1cc(C(C)=O)c2c(c1)-c1ccc(Cl)cc1CN2C</smiles>

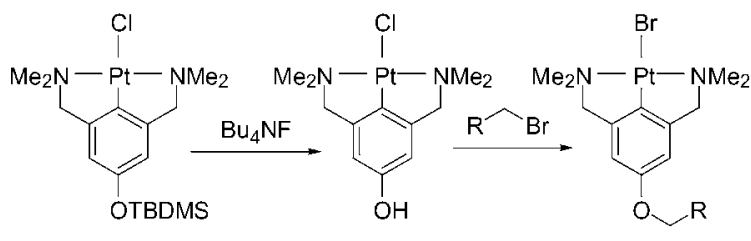

10<smiles></smiles>

13

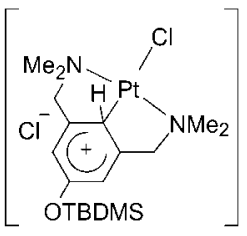

A

Finally, a two-step procedure that gives a similar outcome as route $\mathrm{A}$ involves first reaction of $t$ - BuLi (1.9 equiv) with an $\mathrm{Et}_{2} \mathrm{O}$ solution of $\mathbf{1}$ at $-100{ }^{\circ} \mathrm{C}$. This afforded quantitative and selective lithium-iodide exchange to yield the aryllithium compound $\mathbf{6}$ (Scheme 2, cf. formation of $\mathbf{5}$ in route A).

The chemoselectivity of this reaction was unequivocally demonstrated by quenching a freshly formed solution of $\mathbf{6}$ at $-80{ }^{\circ} \mathrm{C}$ with dry dimethylformamide (DMF), giving rise to the also bifunctionalized pincer ligand 7. Selective metalation of 7 was achieved by applying a similar protocol as shown for $\mathbf{1}$. Reaction of 7 with $\left[\mathrm{Pt}(\mathrm{tol}-4)_{2}\left(\mathrm{SEt}_{2}\right)\right]_{2}$ and $\left[\mathrm{Pd}_{2}(\mathrm{dba})_{3} \cdot \mathrm{CHCl}_{3}\right]$ gave the corresponding complexes $\mathbf{8 a}$ and $\mathbf{9}$, respectively (Scheme 2). The aldehyde moiety of 7 remains unaffected and is accessible for further functionalization.

Organometallic Substrates for Organic Transformations. The observed high selectivity of $\mathbf{1}$ toward different metalating agents gives access to molecules containing two functional sites, i.e., a (potentially catalytically) active organometallic site and an organic site accessible for further transformations. Extended stability of the $\mathrm{M}-\mathrm{C} \sigma$-bond has been illustrated recently for pincer-type systems comprising two supporting $\mathrm{M}-\mathrm{N}$ bonds. ${ }^{19}$ For example, $\mathrm{Si}-\mathrm{O}$ bond cleavage in the organometallic silyl ether $\mathbf{1 0}$ occurs quantitatively in the presence of $\mathrm{Bu}_{4} \mathrm{NF}$ to give the corresponding organoplatinum phenol $[\mathrm{PtCl}(\mathrm{NCN}-\mathrm{OH})] \mathbf{1 1}$ (Scheme 3). ${ }^{19 \mathrm{~d}}$

Subsequent esterification of the phenolic $\mathrm{OH}$-group with various acid chlorides was also achieved with full conservation

(19) (a) Albrecht, M.; Hovestad, N.; Boersma, J.; van Koten, G. Chem. Eur. J. 2001, 7, 1289-1294. (b) Albrecht, M.; Gossage, R. A.; Spek, A. L.; van Koten, G. Chem. Commun. 1998, 1003-1004. (c) Davies, P. J.; Grove, D. M.; van Koten, G. Organometallics 1997, 16, 800-802. (d) Davies, P. J.; Veldman, N.; Grove, D. M.; Spek, A. L.; Lutz, B. T. G.; van Koten, G. Angew. Chem. 1996, 108, 2078-2081; Angew. Chem., Int. Ed. Engl. 1996, $35,1959-1961$. 
Table 3. Resistance of the NCN-Metal Site during Transformations of the Para Functional Center under Specific Reaction Conditions

\begin{tabular}{|c|c|c|c|c|c|}
\hline M & functional group & type of reaction & reagents, conditions & resistance of $\mathrm{Pt}$ & resistance of $\mathrm{Pd}$ \\
\hline $\mathrm{Pt}$ or Pd & $\mathrm{Ar}-\mathrm{OSiMe}_{2} t \mathrm{Bu}$ & desilylation & $\mathrm{BuF}_{4} \mathrm{~N}$ & stable & stable \\
\hline $\mathrm{Pt}$ or Pd & $\mathrm{Ar}-\mathrm{OSiMe}_{2} t \mathrm{Bu}$ & desilylation & $\mathrm{HCl}(2 \mathrm{~N}), 55^{\circ} \mathrm{C}$ & stable & decomposes \\
\hline $\mathrm{Pt}$ or Pd & $\mathrm{Ar}-\mathrm{OH}$ & etherification & acid chloride, amine & stable & stable \\
\hline $\mathrm{Pt}$ or $\mathrm{Pd}$ & $\mathrm{Ar}-\mathrm{OH}$ & esterification & alkyl bromide, $\mathrm{K}_{2} \mathrm{CO}_{3}$ & stable & stable \\
\hline $\mathrm{Pt}$ & $\mathrm{Ar}-\mathrm{OH}$ & deprotonation & $\mathrm{NaOH}, 80^{\circ} \mathrm{C}$ & decomposes & \\
\hline $\mathrm{Pt}$ & $\mathrm{Ar}-\mathrm{CHO}$ & Schiff base reaction & amine & stable & \\
\hline $\mathrm{Pt}$ & $\mathrm{Ar}-\mathrm{CHO}$ & Wittig reaction & $\mathrm{Ph}_{3} \mathrm{P}=\mathrm{CHPh}$ & decomposes & \\
\hline $\mathrm{Pt}$ & $\mathrm{Ar}-\mathrm{CHO}$ & reduction & $\mathrm{LiAlH}_{4}$ & decomposes & \\
\hline $\mathrm{Pt}$ & $\mathrm{Ar}-\mathrm{CHO}$ & reduction & $\mathrm{NaBH}_{4}$ & decomposes & \\
\hline Pt or Pd & $\mathrm{Ar}-\mathrm{CHO}$ & reduction & $\mathrm{NaCNBH}_{3}$ & stable & decomposes \\
\hline $\mathrm{Pt}$ or Pd & $\mathrm{Ar}-\mathrm{I}$ & Sonogashira coupling & acetylene, Pd-cat & stable & stable \\
\hline Pt or Pd & $\mathrm{Ar}-\mathrm{I}$ & oxidative addition & {$\left[\mathrm{M}\left(\mathrm{PPh}_{3}\right)_{4}\right]$} & stable & stable \\
\hline $\mathrm{Pt}$ or Pd & $\mathrm{Ar}-\mathrm{I}$ & lithiation & $t$-BuLi, $100^{\circ} \mathrm{C}$ & stable & decomposes \\
\hline
\end{tabular}

of the platinum-carbon bond. ${ }^{7 \mathrm{a}, 19 \mathrm{~b}, \mathrm{c}}$ Similarly, etherification reactions of $\mathbf{1 0}$ with benzyl bromides has been successfully applied for dendrimer synthesis. ${ }^{19 a}$ These results prompted us to use para-functionalized pincer-platinum complexes and their palladium analogues as substrates for organic transformations. The applied reaction range from mild organic transformations to relatively harsh metal-mediated procedures are compiled in Table 3.

The organometallic substrate $\mathbf{1 1}$ can be prepared from the corresponding silyl ether $\mathbf{1 0}$ with $\mathrm{HCl}$ in air as an alternative procedure to fluoride-mediated $\mathrm{O}-\mathrm{Si}$ bond cleavage. ${ }^{19 \mathrm{~d}}$ Quantitative deprotection with $2 \mathrm{~N}$ aqueous $\mathrm{HCl}$ in acetone occurred at room temperature in $24 \mathrm{~h}$ and at $55^{\circ} \mathrm{C}$ already in $5 \mathrm{~h}$. Platinum(IV) products from metal oxidation have not been detected under these reaction conditions but start to appear when the reaction mixture is left at elevated temperature for prolonged periods $(12 \mathrm{~h})$. Although the detailed mechanism of this reaction is not yet understood, it might involve the formation of a highly reactive arenium intermediate $\mathrm{A}$ (Scheme 3 ), which originates from oxidative addition of $\mathrm{HCl}$ to the metal center and subsequent shift of the proton along the $\mathrm{Pt}-\mathrm{C}$ bond. Similar complexes have been reported to be highly reactive and to readily cleave the oxygen-silicon bond, thus resulting in the elimination of the tert-butyldimethylsilyl group. ${ }^{20}$

The resistance of the $\eta^{3}-\mathrm{N}, \mathrm{C}, \mathrm{N}$-coordinated NCN-platinum unit toward an acidic or oxidizing environment prompted us to further investigate these complexes as organometallic substrates for reductions. The reaction of $[\mathrm{PtBr}(\mathrm{NCN})]$ with $\mathrm{LiAlH}_{4}$ has been reported to yield decomposition products, probably via formation of a highly unstable complex containing a platinumbound hydride, although the expected halfway-formed cationic intermediate $[\mathrm{NCNPtHPtNCN}]^{+}$is stable. ${ }^{21}$ This undesired reactivity was anticipated to be circumvented by use of $\mathrm{NaBH}_{4}$ as reducing agent, since $\mathrm{LiAlH}_{4}$ and $\mathrm{NaBH}_{4}$ are often complementary in terms of reactivity. ${ }^{22}$ When a solution of $8 \mathbf{a}$ was treated with $\mathrm{NaBH}_{4}$ (2.0 equiv) in methanol at $0{ }^{\circ} \mathrm{C}, 50 \%$ conversion to the benzylic alcohol $\mathbf{1 4}$ was observed after 30 min (Scheme 4).

The presence of $\mathbf{1 4}$ was clearly indicated by a new singlet in the ${ }^{1} \mathrm{H}$ NMR spectrum at $4.50 \mathrm{ppm}$ for the benzylic $\mathrm{ArCH}_{2} \mathrm{OH}$ and a reduced integral of the resonance due to the aldehyde

(20) Albrecht, M.; Spek, A. L.; van Koten, G. J. Am. Chem. Soc. 2001, 123, $7233-7246$.

(21) (a) Terheijden, J.; van Koten, G.; Grove, D. M.; Vrieze, K.; Spek, A. L. J. Chem. Soc., Dalton Trans. 1987, 1359-1366. (b) Grove, D. M.; van Koten, G.; Ubbels, H. J. C.; Spek, A. L. J. Am. Chem. Soc. 1982, 104, 42854286.

(22) March, J. Advanced Organic Chemistry; 4th ed., Wiley: New York, 1992.
Scheme 4. Pincer-Pt" Complexes for Organic Transformations ${ }^{a}$

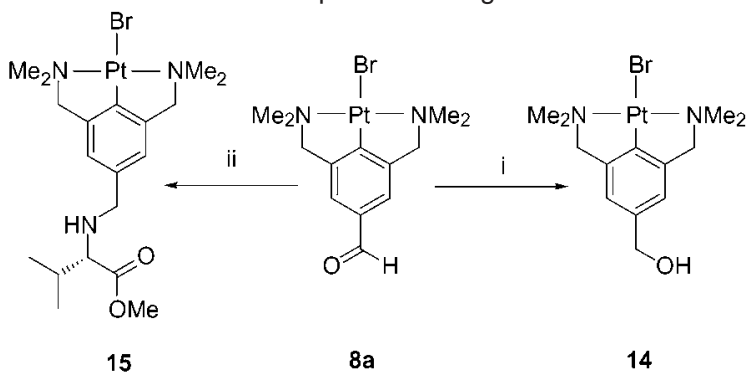

${ }^{a}$ Reagents and conditions: (i) $\mathrm{AcOH}, \mathrm{NaBH}_{3} \mathrm{CN}, \mathrm{MeOH}, 10^{\circ} \mathrm{C} \rightarrow \mathrm{RT}$, 1 h. (ii) (a) L-Val-OMe $\cdot \mathrm{HCl}, \mathrm{NEt}_{3}, \mathrm{RT}, 12 \mathrm{~h}$; (b) $\mathrm{AcOH}, \mathrm{NaBH}_{3} \mathrm{CN}, \mathrm{MeOH}$, $10{ }^{\circ} \mathrm{C} \rightarrow \mathrm{RT}, 2 \mathrm{~h}$

protons. Unfortunately, longer reaction times led to decomposition products and pure $\mathbf{1 4}$ could not be isolated from this reaction. Ultimately, the aldehyde functionality in $\mathbf{8 a}$ was successfully reduced by using $\mathrm{NaBH}_{3} \mathrm{CN}$ as a less reactive hydride source. Treatment of a methanol solution of $\mathbf{8 a}$ and $\mathrm{AcOH}$ (1.0 equiv) at a temperature below $10{ }^{\circ} \mathrm{C}$ with $\mathrm{NaBH}_{3}-$ $\mathrm{CN}$ (2.0 equiv) led to the stable platinated complex 14 .

The remarkable stability of the pincer-platinum(II) unit toward reducing conditions has been applied in, for example, the functionalization of biologically active substances with pincer-metal units. ${ }^{23}$ Thus, covalent attachment of the pincerplatinum building block $\mathbf{8 a}$, via the aldehyde functionality, to the N-terminus of the C-protected amino acid Val-OMe was achieved under Schiff base reaction conditions. Subsequent reduction of the resulting imine with $\mathrm{NaBH}_{3} \mathrm{CN}$ gave the $\mathrm{N}$-functionalized amino acid $\mathbf{1 5}$ in good yields (Scheme 4).

The NCN-palladium site is less resistant to these reagents than the corresponding platinum analogues. For example, reaction of the palladium analogue of $\mathbf{1 0}$ with $\mathrm{HCl}$ leads to concomitant $\mathrm{Si}-\mathrm{O}$ and $\mathrm{Pd}-\mathrm{C}$ bond cleavage (Scheme 3). ${ }^{24}$ Also, $\mathrm{NaBH}_{3} \mathrm{CN}$-mediated reduction reactions with the palladium complex 9 failed and the expected benzylic alcohol was not obtained. ${ }^{1} \mathrm{H}$ NMR analysis of the crude reaction mixture clearly revealed that the nitrogen groups are not coordinated to the $\mathrm{Pd}$ center since the resonance signals of the $\mathrm{ArCH}_{2} \mathrm{~N}$ and the $\mathrm{NMe}_{2}$ protons appeared at a field typical for the metal-free ligand precursor. Moreover, the presence of one signal at 10 ppm typical for aldehyde moieties and another one at $7.58 \mathrm{ppm}$

(23) Albrecht, M.; Rodríguez, G.; Schoenmaker, J.; van Koten, G. Org. Lett. 2000, 2, 3461-3464

(24) Notably, the softer deprotection method using fluoride anions induces $\mathrm{Si}-\mathrm{O}$ bond cleavage and affords the desired organopalladium phenol in good yields. 
Scheme 5. Metal-Mediated Transformations of Pincer-M" Complexes $^{a}$
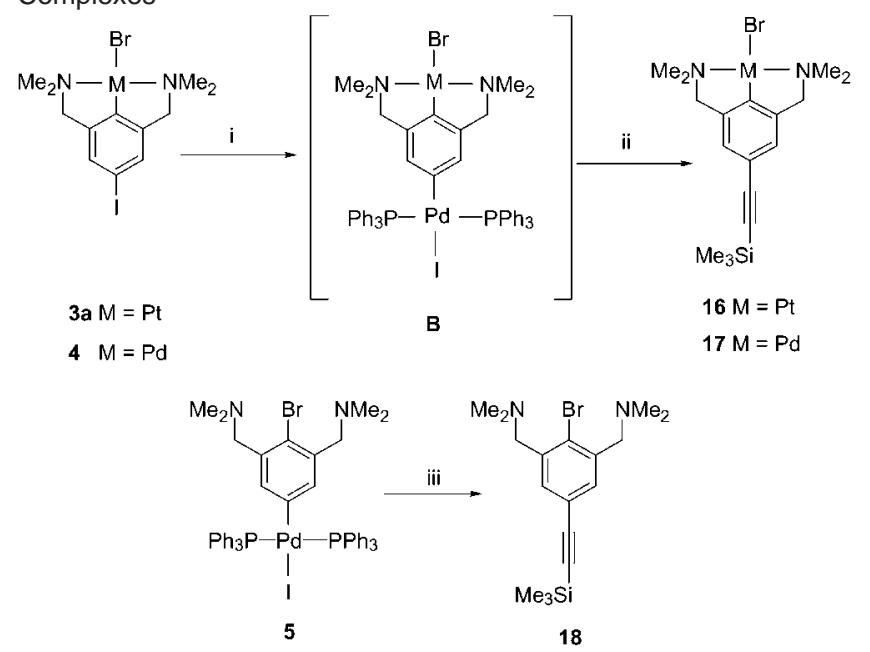

${ }^{a}$ Reagents and conditions: (i) $\left[\mathrm{PdCl}_{2}\left(\mathrm{PPh}_{3}\right)_{2}\right], \mathrm{CuI}, \mathrm{Et}_{2} \mathrm{NH}, \mathrm{RT}, 12 \mathrm{~h}$. (ii) $\mathrm{Me}_{3} \mathrm{SiC} \equiv \mathrm{CH}$. (iii) $\mathrm{Me}_{3} \mathrm{SiC} \equiv \mathrm{CH}, \mathrm{Et}_{2} \mathrm{NH}, \mathrm{RT}, 12 \mathrm{~h}$.

(both integrate for one proton) suggested that the borohydride reagent is preferentially consumed by addition to the $\mathrm{Pd}-\mathrm{C}$ bond rather than to the $\mathrm{C}=\mathrm{O}$ aldehyde functionality.

Notably, bases such as $\mathrm{NaNH}_{2}, \mathrm{NaOMe}, n$-BuLi, or other $n$-alkyllithium reagents ${ }^{25}$ except for $t$-BuLi (vide infra) have been found to be incompatible with all of the studied complexes since they promote demetalation reactions. This susceptibility of the $\mathrm{M}-\mathrm{C}$ bond to nucleophilic bases may be due to an anion exchange of the base with the metal-bound halide and subsequent decomplexation, perhaps via $\alpha$ - or $\beta$-hydrogen elimination pathways. Accordingly, Wittig-type reactions with $\mathbf{8 a}$ as the substrate failed due to the presence of $\mathrm{NaOMe}$ for ylide formation.

Palladium-mediated $\mathrm{C}-\mathrm{C}$ bond formation reactions at the para position of pincer-metal complexes have been examined by using substrates $\mathbf{3 a}$ and $\mathbf{4}$, which both contain, in addition to a $\mathrm{C}-\mathrm{M}$ bond, a reactive $\mathrm{C}_{\text {aryl }}-\mathrm{I}$ bond. For example, $\mathrm{C}_{\text {aryl }}-\mathrm{C}_{\text {aryl }}$ bond formation was probed by using the Suzuki coupling protocol. ${ }^{26}$ However, even after prolonged heating of the platinum(II) complex $\mathbf{3 a}$ in the presence of $\mathrm{PhB}(\mathrm{OH})_{2}$ and catalytic amounts of a suitable palladium salt and $\mathrm{Na}_{2} \mathrm{CO}_{3}$, the anticipated coupling was not observed. Instead, the starting material 3a was recovered along with another organoplatinum product, which most probably resulted from bonding of a derivative of the boronic acid to the metal center of the $\mathrm{NCN}^{-}$ platinum complex.

Milder reaction conditions, which avoid the use of inorganic bases such as $\mathrm{Na}_{2} \mathrm{CO}_{3}$ (vide supra), are used in the Sonogashira reaction. ${ }^{27}$ Reaction of $\mathbf{3 a}$ with (trimethylsilyl)acetylene in the presence of catalytic amounts of $\mathrm{CuI}$ and $\left[\mathrm{PdCl}_{2}\left(\mathrm{PPh}_{3}\right)_{2}\right]$ afforded the desired para-alkynylated NCN-Pt(II) complex 16 in reasonable yield (60\%; Scheme 5). ${ }^{28}$

The same reactivity and stability were observed for the $\mathrm{NCN}-\mathrm{Pd}$ complex $\mathbf{4 a}$, i.e., under these conditions, not only the

(25) In contrast, aryllithium compounds or lithium acetylides react with $\mathrm{NCN}-$ platinum and palladium halide complexes in an anion-exchange reaction; for details, see ref $14 \mathrm{a}$.

(26) Miyaura, N.; Suzuki, A. Chem. Rev. 1995, 95, 2457-2483.

(27) Sonogashira, K.; Tohda, Y.; Hagihara, N. Tetrahedron, Lett. 1975, 16, 4467-4470. (b) Takahashi, S.; Kuroyama, Y.; Sonogashira, K.; Hagihara, N. Synthesis 1980, 627-630.

(28) James, S. L.; Verspui, G.; Spek, A. L.; van Koten, G. Chem. Commun. 1996, 1309-1310.
$\mathrm{NCN}$ - platinum but also the $\mathrm{NCN}$-palladium complex proved to be suitable substrates. Compound $\mathbf{5}$ is the proposed intermediate in the Sonogashira coupling with $\mathbf{1}$ as substrate. ${ }^{29}$ Accordingly, stoichiometric amounts of $\mathbf{5}$ were reacted with trimethylsilylacetylene in $\mathrm{Et}_{2} \mathrm{NH}$ as a solvent, affording the exclusive formation of ligand $\mathbf{1 8} .^{30}$ Thus, the transformation of $\mathbf{3 a}$ and $\mathbf{4 a}$ into the acetylenic products $\mathbf{1 6}$ and $\mathbf{1 7}$, respectively, involves the transient formation of a (hetero)bimetallic arenediylbridged intermediate $\mathrm{B}$ (Scheme 5).

(Hetero)Bimetallic Complexes as Building Blocks for New Materials. Bimetallic transition-metal complexes with $\pi$-delocalized bridging ligands display intriguing electronic and photophysical properties since electronic "communication" between the metal centers is facilitated. ${ }^{31}$ Therefore, such species can be used as building blocks for the synthesis of conducting organometallic oligomers and polymers ("molecular wires") ${ }^{32}$ and for materials exhibiting nonlinear optical (NLO) properties. ${ }^{33}$ This wide range of possible applications prompted us to study the synthesis and isolation of stable bimetallic complexes from ligand 1 by a double oxidative addition strategy. The results obtained in the Sonogashira $\mathrm{C}-\mathrm{C}$ coupling reaction are already good evidence for the formation of these systems since the heterobimetallic complex B (Scheme 5) is supposed to be a key intermediate.

A logical strategy for the preparation of such bimetallic complexes comprises the oxidative addition of $\left[\mathrm{M}\left(\mathrm{PPh}_{3}\right)_{4}\right]$ to the aryl-iodide bond of 3 . Previous reports have shown, however, that the hard amine ligands in cyclometalated platinum complexes are replaced quantitatively by $\mathrm{PPh}_{3} .{ }^{14 b, 34}$ Since the oxidative addition of $\left[\mathrm{M}\left(\mathrm{PPh}_{3}\right)_{4}\right]$ includes the release of $\mathrm{PPh}_{3}$, partial substitution of the amines in $\mathbf{3}$ and hence product mixtures such as $\mathrm{C}$ were expected (Scheme 6). To avoid this, phosphine complex $\mathbf{1 9}$ has been used as starting material (Scheme 6). This complex was readily obtained after 3a was first stirred in a NaI/acetone mixture and subsequently in benzene in the presence of stoichiometric amounts of $\mathrm{PPh}_{3}$. The singlet at $16.88 \mathrm{ppm}$ in the ${ }^{31} \mathrm{P}$ NMR spectrum $\left({ }^{1} J_{\mathrm{PtP}}=2988.6\right.$ $\mathrm{Hz}$ ) is indicative for platinum-bound $\mathrm{PPh}_{3}$ groups in mutual trans position.

An X-ray crystal structure determination of $\mathbf{1 9}$ confirmed the proposed connectivity pattern (Figure 2; relevant bond distances and angles are given in Table 1). The molecular structure of $\mathbf{1 9}$ shows a square-planar platinum(II) complex that possesses two $\mathrm{PPh}_{3}$ ligands in mutual trans configuration and a monodentate $\eta{ }^{1}$-C-bonded NCN ligand, i.e. the two $o$-amino substituents are not coordinated. The coordination plane of the platinum(II) center is perpendicular to the NCN plane, which is in agreement with the structural features of other closely related compounds earlier reported. ${ }^{34}$ This perpendicular conformation has also been found for 2 containing a $\mathrm{Pt}-\mathrm{C}$ bond at the para position of the NCN site (cf. Figure 1a).

(29) Katritzky, R. A.; Meth-Cohn, O.; Rees, W. C. Comprehensive Organic Functional Transformations, Pergamon: Oxford, U.K., 1995.

(30) Back, S.; Albrecht, M.; Spek, A. L.; Rheinwald, G.; Lang, H.; van Koten, G. Organometallics 2001, 20, 1024-1027.

(31) Sauvage, J.-P.; Collin, J.-P.; Chambron, J.-C.; Guillerez, S.; Coudret, C. Chem. Rev. 1994, 94, 993-919.

(32) Martin, R. E.; Diederich, F. Angew. Chem. 1999, 111, 1440-1469; Angew. Chem., Int. Ed. 1999, 38, 1350-1357.

(33) Long, N. J. Angew. Chem. 1995, 107, 37-54; Angew. Chem., Int. Ed. Engl. 1995, 34, 21-38.

(34) Albrecht, M.; Dani, P.; Lutz, M.; Spek, A. L.; van Koten, G. J. Am. Chem. Soc. 2000, 122, 11822-11833. 
Scheme 6. Synthesis of (Hetero)Bimetallic Complexes ${ }^{a}$
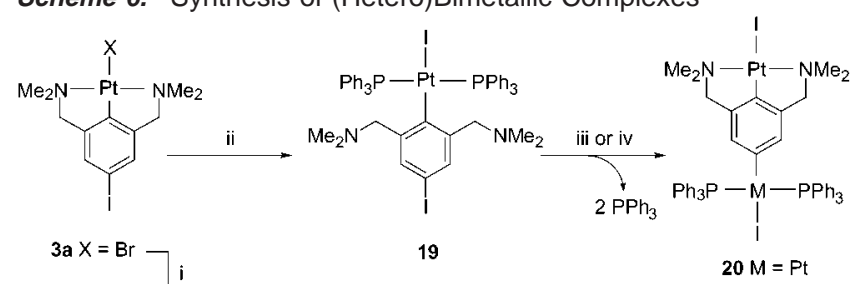

$\left.\begin{array}{l}3 \mathbf{a} X=\mathrm{Br} \\ 3 \mathbf{b} X=1\end{array}\right]$ i

19

$20 \mathrm{M}=\mathrm{Pt}$

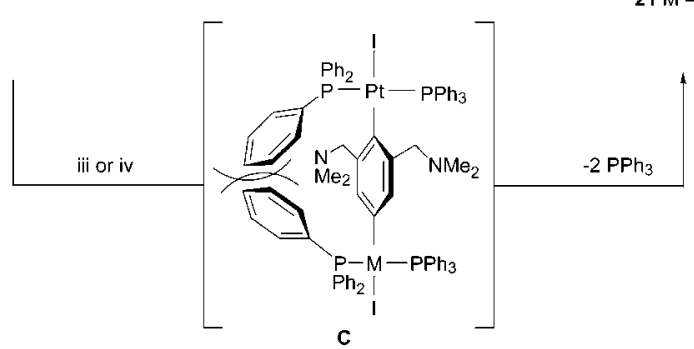

${ }^{a}$ Reagents and conditions: (i) (a) $\mathrm{AgBF}_{4}$, acetone/ $\mathrm{CH}_{2} \mathrm{Cl}_{2}, \mathrm{RT}, 30 \mathrm{~min}$; (b) NaI, acetone, RT, 12 h. (ii) $\mathrm{PPh}_{3}$, benzene, RT, 12 h. (iii) $\left[\mathrm{Pt}\left(\mathrm{PPh}_{3}\right)_{4}\right]$, toluene, $50{ }^{\circ} \mathrm{C}, 12 \mathrm{~h}$. (iv) $\left[\mathrm{Pd}\left(\mathrm{PPh}_{3}\right)_{4}\right]$, toluene, RT, $15 \mathrm{~min}$.

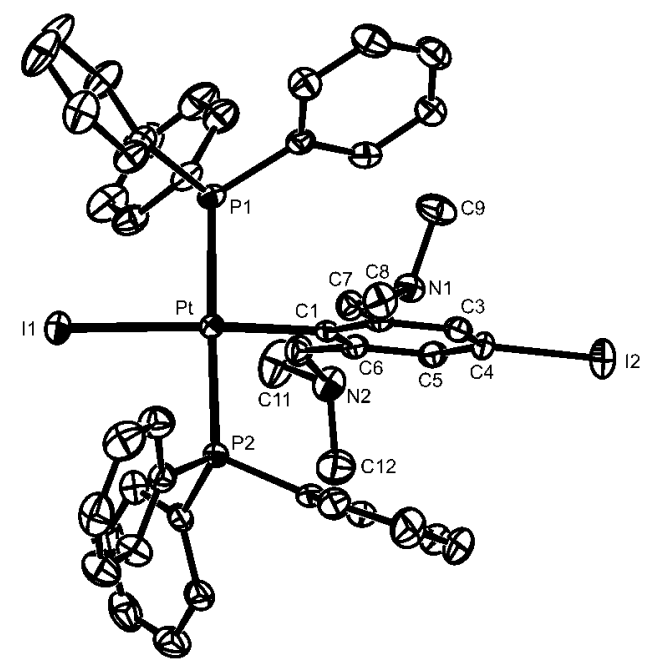

Figure 2. Displacement ellipsoid plot (50\% probability) of compound 19. Hydrogen atoms and the disordered $\mathrm{CH}_{2} \mathrm{Cl}_{2}$ solvent molecules have been omitted for clarity.

Metal insertion into the para $\mathrm{C}_{\text {aryl }}-\mathrm{I}$ bond of the $\eta^{1}-\mathrm{C}$ pincerplatinum compound 19 was accomplished by oxidative addition with stoichiometric amounts of $\left[\mathrm{M}\left(\mathrm{PPh}_{3}\right)_{4}\right](\mathrm{M}=\mathrm{Pt}, \mathrm{Pd})$. These reactions afforded the homobimetallic $\mathrm{Pt}_{2}$ species 20 and the heterobimetallic analogue 21, respectively (Scheme 6). Most interestingly, the formed product showed only one type of platinum-bound phosphines $\left(\delta_{\mathrm{P}}=22.3,{ }^{1} J_{\mathrm{PtP}}=3091.6 \mathrm{~Hz}\right.$ for 20, $\delta_{\mathrm{P}}=23.4$ for 21). Moreover, the ${ }^{1} \mathrm{H}$ NMR spectra of both complexes clearly reveal ${ }^{195} \mathrm{Pt}$ satellites on the resonances attributed to the $\mathrm{ArCH}_{2} \mathrm{~N}$ and $\mathrm{NMe}_{2}$ protons. This strongly indicates that the nitrogen donors of the $\mathrm{NCN}$ ligand are coordinated to the platinum center. A single-crystal structure determination of $\mathbf{2 0}$ unambiguously confirmed these assignments. The molecular structure is depicted in Figure 3 and shows two square-planar platinum(II) centers that are interconnected by the aryl ring of the NCN ligand.

One platinum center is bound to two phosphine ligands as well as via an $\eta^{1}-\mathrm{C}$ bond to the para position of the pincer ligand. The other metal center is bound in a well-established $\eta^{3}-\mathrm{N}, \mathrm{C}, \mathrm{N}$ terdentate coordination mode. ${ }^{14}$ The difference in binding is

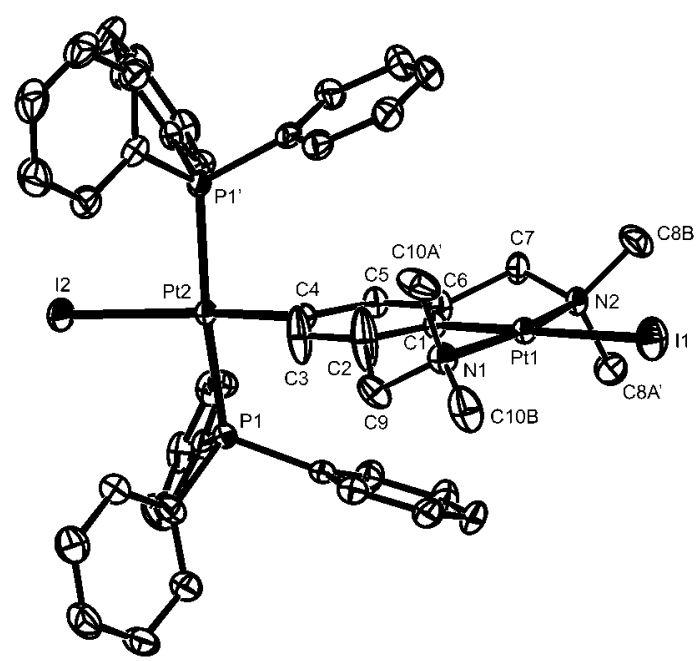

Figure 3. Displacement ellipsoid plot (50\% probability) of the pincerdiplatinum(II) compound 20. The pincer ligand is disordered over the crystallographic mirror plane of space group Pnma. Only one disorder component is shown. Hydrogen atoms and the $\mathrm{C}_{6} \mathrm{H}_{6}$ solvent molecule have been omitted for clarity. Symmetry operation: $x, 0.5-y, z$.

clearly reflected by the $\mathrm{Pt}-\mathrm{C}$ bond length, which is shorter in the $\eta^{3}-\mathrm{N}, \mathrm{C}, \mathrm{N}$ platinum moiety than in the $\eta^{1}-\mathrm{C}$ platinum monodentate site [cf. Pt1-C1 1.925(5) $\AA$ vs Pt2-C4 2.021(5) $\AA]$. Notably, the NCN aryl ring is disordered over a crystallographic mirror plane and is therefore essentially perpendicular to the coordination plane of $\mathrm{Pt} 2$ containing symmetry-related phosphine ligands.

Remarkably, the expected compound $\mathrm{C}$ has not been detected. Instead the Pt center, which is initially $\eta^{1}$-C-bound in $\mathbf{1 9}$, has become $\eta^{3}-\mathrm{N}, \mathrm{C}, \mathrm{N}$-coordinated in 20. Species $\mathrm{C}$ may be an unstable intermediate rather than an end product as a result of the steric hindrance of the four $\mathrm{PPh}_{3}$ groups at the para positions. It must be noted that the repulsion of the ortho substituents on the bridging arene ring would force the two coordination planes and the arenediyl ring to be in mutually perpendicular orientations.

Moreover, bimetallic complexes $\mathbf{2 0}$ and $\mathbf{2 1}$ were also directly prepared from $\mathbf{3 b}$ and $\left[\mathrm{M}\left(\mathrm{PPh}_{3}\right)_{4}\right]$. Indeed, formation of the intermediate $\mathrm{C}$ could be observed by ${ }^{1} \mathrm{H}$ NMR, but as earlier indicated, these compounds were not stable enough and they converted within $1 \mathrm{~h}$ into $\mathbf{2 0}$ and $\mathbf{2 1}$, respectively.

Metal insertion into the para $\mathrm{C}_{\text {aryl }}-\mathrm{Br}$ bond of the $\eta^{1}-\mathrm{C}$ pincer-platinum complex $\mathbf{2}$ was also accomplished by oxidative addition of $\left[\mathrm{Pd}\left(\mathrm{PPh}_{3}\right)_{4}\right]$. This procedure gave the corresponding bimetallic complex 22 with an $\eta^{3}$-N,C,N-coordinated palladium center (Scheme 7). Notably, scrambling of the palladium-bound halide was observed during this reaction, thus affording a mixture of iodide and bromide species. Complete anion exchange was accomplished by addition of NaI. The NMR spectroscopic properties of $\mathbf{2 2}$ are closely related to those of the parent platinum complexes 20 and 21, except for the ${ }^{195}$ $\mathrm{Pt}-{ }^{1} \mathrm{H}$ couplings $\left({ }^{3} J_{\mathrm{PtH}}=56.1 \mathrm{~Hz}\right.$, Table 1$)$ for the aromatic protons, which were not observed in $\mathbf{2 1}$.

The synthesis of the bispalladated complex $\mathbf{2 3}$ required the preparation and immediate reaction of $\mathbf{4 b}$ with $\left[\mathrm{Pd}\left(\mathrm{PPh}_{3}\right)_{4}\right]$ due to its low stability. The resulting bimetallic complex is more stable than $\mathbf{4 b}$ and could be easily analyzed (Scheme 7).

Another interesting and successful strategy toward the preparation of bimetallic complexes involves the substitution 
Scheme 7. Synthesis of Pincer-(Hetero)Bimetallic Complexes ${ }^{a}$
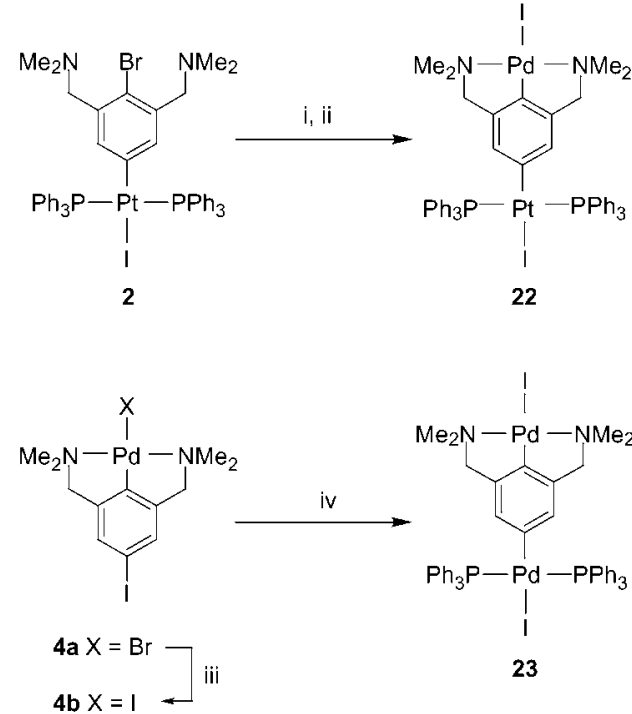

${ }^{a}$ Reagents and conditions: (i) $\left[\mathrm{Pd}_{2}(\mathrm{dba})_{3} \cdot \mathrm{CHCl}_{3}\right]$, benzene, $\Delta, 15 \mathrm{~min}$. (ii) $\mathrm{NaI}$, acetone, $\mathrm{RT}, 12 \mathrm{~h}$. (iii) (a) $\mathrm{AgBF}$, acetone $/ \mathrm{CH}_{2} \mathrm{Cl}_{2}, \mathrm{RT}, 30 \mathrm{~min}$; (b) NaI, acetone, RT, 12 h. (iv) $\left[\mathrm{Pd}\left(\mathrm{PPh}_{3}\right)_{4}\right]$, benzene, $0{ }^{\circ} \mathrm{C}, 1 \mathrm{~h}$.

of an aryl-bound halide by a lithium/halide exchange reaction. When a tetrahydrofuran (THF) solution of $\mathbf{3 a}$ at $-100{ }^{\circ} \mathrm{C}$ was treated with $t$-BuLi (2.0 equiv), lithium/iodide exchange took place and a bimetallic Li/Pt species D was formed (Scheme 8). The chemoselectivity of the lithiation was unambiguously demonstrated by quenching this solution with DMF, which yielded the air-stable aldehyde $\mathbf{8 a}$. Remarkably, the $\eta^{3}-\mathrm{N}, \mathrm{C}, \mathrm{N}-$ metal unit remains unaffected during this two-step process. Concomitant formation of LiI caused partial anion exchange, which was completed by subsequent addition of excess NaI. This reaction sequence afforded the iodide compound $\mathbf{8 b}$.

The selective reactivity patterns and the outstanding stability properties of the $\eta^{3}-\mathrm{N}, \mathrm{C}, \mathrm{N}$-pincer platinum unit toward alkyllithium reagents have been used for the development of a novel straightforward protocol for the synthesis of metallodendrimers containing one or several pincer-(transition) metal sites in their structure (at the core or periphery). Metallodendrimers have found use as homogeneous catalysts, light-harvesting antennas, and sensor materials. ${ }^{35}$

So far, peripheral functionalization of carbosilane dendrimers with catalytically active NCN-metal moieties has been accomplished by coupling of the para-lithiated pincer ligand precursor with $\mathrm{Si}-\mathrm{Cl}$ bonds on the dendritic periphery, followed by metal insertion para to the $\mathrm{Si}-\mathrm{C}$ bond. ${ }^{36}$ This metalation is often incomplete, especially for higher-generation dendrimers containing a large number of peripheral sites, thus causing the introduction of mistakes in the dendritic structure of the metallodendrimer. The use of organometallic building blocks

(35) See, for example, (a) Fischer, M.; Vögtle, F. Angew. Chem. 1999, 111 934-955; Angew. Chem., Int. Ed. 1999, 38, 884-905. (b) Hearshaw, M. A.; Moss, J. R. Chem. Commun. 1999, 1-8. (c) Newkome, G. R.; He, E.; Moorefield, C. N. Chem. Rev. 1999, 99, 1689-1746. (d) Bosman, A. W. Janssen, H. M.; Meijer, E. W. Chem. Rev. 1999, 99, 1665-1688.

(36) For examples, see (a) Kleij, A. W.; Gossage, R. A.; Klein Gebbink, R. J. M.; Brinkmann, N.; Reijerse, E. J.; Kragl, U.; Lutz, M.; Spek, A. L.; van Koten, G. J. Am. Chem. Soc. 2000, 122, 12112-12124. (b) Köllner, C.; Pugin, B.; Togni, A. J. Am. Chem. Soc. 1998, 120, 10274-10275. (c) Reetz, M. T.; Lohmer, G.; Schwickardi, R. Angew. Chem. 1997, 109, 1559-1562; Angew. Chem., Int. Ed. Engl. 1997, 36, 1526-1529. For exceptions, i.e., metal insertion before the last steps, see e.g. ref 15 and (d) Constable, E. C. Chem. Commun. 1997, 1073-1080.
Scheme 8. Synthesis of Organometallic Polymers (cf. 25) and Dendrimer Mimics (cf. 24) from Pincer-Platinum Building Blocks ${ }^{a}$<smiles>[Y][PH]1(C)c2c(CN)cc(C=O)cc2CN1C</smiles>

$8 \mathrm{a} X=\mathrm{Br} \rightarrow$ ii $8 b x=1 \_$il

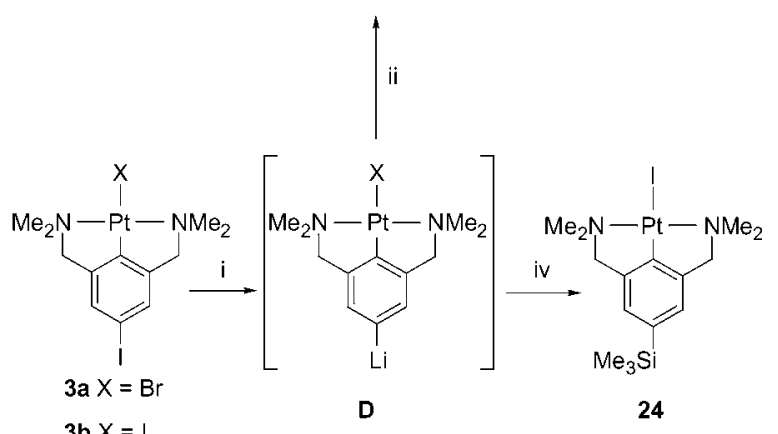

$3 \mathbf{b} \times=1$

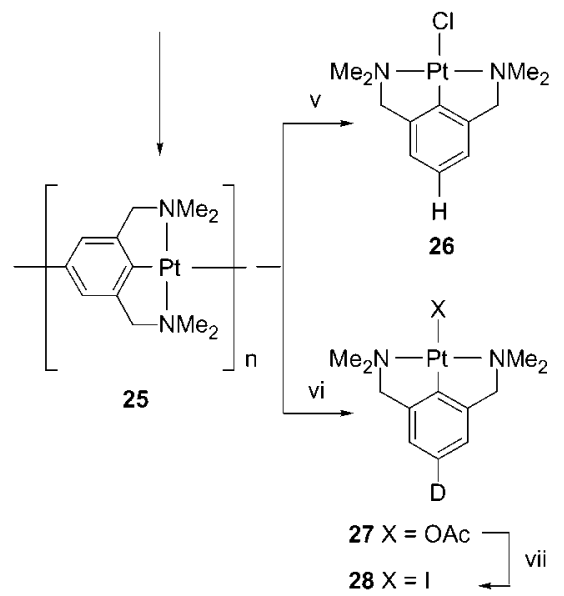

${ }^{a}$ Reagents and conditions: (i) $t$ - $\mathrm{BuLi}, \mathrm{Et}_{2} \mathrm{O},-100^{\circ} \mathrm{C}$. (ii) (a) DMF; (b) $\mathrm{AgBF}_{4}$, acetone, RT; (c) $\mathrm{NaI}$, acetone, $\mathrm{RT}$. (iii) $\mathrm{Me}_{3} \mathrm{SiCl}$. (iv) $\mathrm{HCl}$. (v) $\mathrm{Ac}_{2} \mathrm{O} /$ $\mathrm{D}_{2} \mathrm{O}$. (vi) NaI.

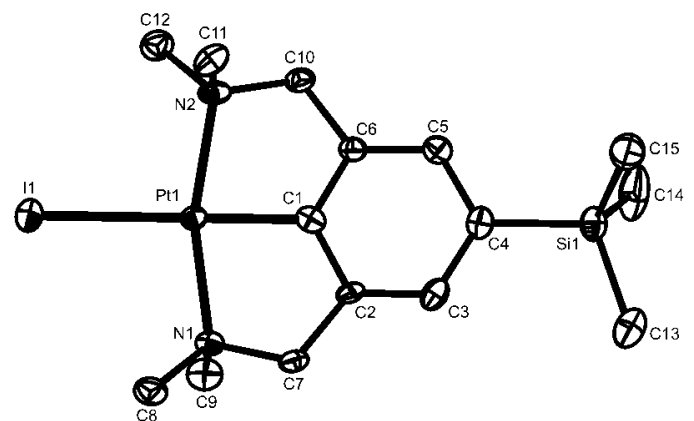

Figure 4. Displacement ellipsoid plot (50\% probability) of $p$-silylfunctionalized pincer $-\mathrm{Pt}^{\mathrm{II}} \mathbf{2 4}$. Hydrogen atoms have been omitted for clarity.

such as $\mathbf{3}$ avoids this final metalation step and provides convergent synthetic protocols for the synthesis of peripheryfunctionalized dendritic structures. We have tested this approach by reacting lithiated $\mathbf{3 b}$ with $\mathrm{Me}_{3} \mathrm{SiCl}$ as the simplest model substrate of a reactive carbosilane dendritic surface. This afforded $\mathbf{2 4}$ containing a new para $\mathrm{C}-\mathrm{Si}$ bond in nearly quantitative yield (Scheme 8). According to NMR spectroscopy and also an X-ray structure determination (see Figure 4), no metal decomplexation occurred under these reaction conditions. 
Strict control of the temperature is essential during the lithium/ halide exchange reaction of $\mathbf{3 b}$, since selective para-lithiation of $\mathbf{3 b}$ occurs selectively only at temperatures around $-100^{\circ} \mathrm{C}$. At higher temperatures a white precipitate formed, which was isolated by repeated washing with THF. The material, which appeared to be insoluble in water and common organic solvents, has been tentatively assigned a polymeric structure $[\mathrm{Pt}(\mathrm{NCN})]_{n}$ 25 (Scheme 8). Such a product may result from substitution of the metal-bound halide by the aryl anion of the pincer-lithium species, which is known to give complexes of the type [Pt$(\operatorname{aryl})(\mathrm{NCN})]$ containing a new $\mathrm{Pt}-\mathrm{C}_{\text {aryl }}$ bond (cf. $[\mathrm{Pt}(\mathrm{NCN})-$ $\left.\left\{1-\mathrm{C}_{6} \mathrm{H}_{2}\left(\mathrm{CH}_{2} \mathrm{NMe}_{2}\right)-3,5\right\}\right] .{ }^{14 a, 37}$ Condensation of the bifunctional intermediate $\mathrm{D}$ obviously provides polymeric structures. The postulation of $\mathbf{2 5}$ as polymeric material is further supported by the reactivity of this solid. For example, addition of $\mathrm{HCl}$ to a suspension of $\mathbf{2 5}$ in acetone induced a rapid formation of a clear solution. Spectroscopic analysis $\left({ }^{1} \mathrm{H},{ }^{13} \mathrm{C} \mathrm{NMR}\right)$ of this solution revealed the presence of $[\mathrm{PtCl}(\mathrm{NCN})] \mathbf{2 6}$ exclusively, as it was established by comparison with an authentic sample. ${ }^{21 a}$ Similarly, reaction of $\mathbf{2 5}$ with a mixture of $\mathrm{Ac}_{2} \mathrm{O} / \mathrm{D}_{2} \mathrm{O}$ resulted in the clean formation of the deuterated complex 27, which was easily converted in its iodide analogue $\mathbf{2 8}$ by treatment of the reaction mixture with $\mathrm{NaI}^{38}{ }^{38}$ Due to the insolubility of $\mathbf{2 5}$, we have not been able yet to determine the polydispersity index (PDI) nor the average molecular weight of the polymeric material.

\section{Conclusions}

We have established methods for the selective monometalation of the bifunctional ligands of which $\mathbf{1}$ is a representative example. Excellent chemoselectivites have been obtained by appropriate variation of the metal precursors and reaction conditions, which allowed for product distributions that were controlled by kinetic (e.g., higher reactivity of the $\mathrm{C}_{\text {aryl }}-\mathrm{I}$ bond) or by thermodynamic factors (e.g., stability through chelation). This provided organometallic building blocks that contain a second functional group for further functionalization. A range of synthetic protocols have been developed that allow for the modification of these groups by organic and also organometallic reactions without affecting the $\mathrm{M}-\mathrm{C} \sigma$-bond of the organometallic moiety. This disclosed a novel strategy for the fabrication of materials with organometallic active sites, which is based on the use of metalated building blocks. This has been illustrated by the synthesis of dendritic mimics, biomolecular pincerplatinum structures, ${ }^{23}$ and by the preparation of polymers containing organometallic main chains, cf. $[\mathrm{Pt}(\mathrm{NCN})]_{n}, 25$. Currently, we are investigating the application potential of such structures in molecular electronics.

\section{Experimental Section}

General. All manipulations involving organolithium compounds were performed under a dry and deoxygenated nitrogen atmosphere by standard Schlenk techniques. Solvents were carefully dried and distilled from sodium benzophenone (pentane, hexane, toluene, $\mathrm{C}_{6} \mathrm{H}_{6}$, $\left.\mathrm{THF}, \mathrm{Et}_{2} \mathrm{O}\right)$ or $\mathrm{CaH}\left(\mathrm{CH}_{2} \mathrm{Cl}_{2}, \mathrm{DMF}\right)$ prior to use. Flash chromatography was performed on 230-400 mesh silica or 70-300 mesh aluminum

(37) Albrecht, M.; James, S. L.; Veldman, N.; Spek, A. L.; van Koten, G. Can. J. Chem. 2001, 79, 709-718.

(38) The $p$-deuterated compound $\mathbf{2 8}$ was identified by its ${ }^{1} \mathrm{H}$ NMR spectrum, which was identical to that of $[\mathrm{PtI}(\mathrm{NCN})]$ except for the aromatic part, where a singlet at $6.82 \mathrm{ppm}$ is observed instead of the doublet at $6.83 \mathrm{ppm}$ and the triplet at $7.03 \mathrm{ppm}$ corresponding to $[\mathrm{PtI}(\mathrm{NCN})] .^{21 \mathrm{~b}}$ oxide (Merck). Please note that a full description of the experimental procedures and analytical data for the synthesis of compound $\mathbf{1}$ has been deposited as Supporting Information. The metal salts [Pt(tol-4) $2_{2}^{-}$ $\left.\left(\mathrm{SEt}_{2}\right)\right]_{2},{ }^{39}\left[\mathrm{Pd}_{2}(\mathrm{dba})_{3} \cdot \mathrm{CHCl}_{3}\right],{ }^{40}$ and $\left[\mathrm{Pd}\left(\mathrm{PPh}_{3}\right)_{4}\right]^{40}$ and complex $\mathbf{1 0}^{19 \mathrm{~d}}$ were synthesized according to literature procedures. All other chemicals were obtained commercially and used without further purification. NMR spectra were recorded at $25{ }^{\circ} \mathrm{C}$ and were referenced to $\operatorname{SiMe}_{4}(\delta=$ $0.00, J$ values are given in hertz; ${ }^{1} \mathrm{H}$ and ${ }^{13} \mathrm{C}$ NMR $)$ or $\mathrm{H}_{3} \mathrm{PO}_{4}\left({ }^{31} \mathrm{P}\right.$ NMR). Elemental analyses were performed by Dornis and Kolbe, Mikroanalytisches Laboratorium (Mülheim a.d. Ruhr, Germany). Residual solvent molecules were identified by ${ }^{1} \mathrm{H}$ NMR spectroscopy. Matrix-assisted laser desorption ionization time-of-flight (MALDI-TOF) mass spectra were acquired by use of a Voyager-DE BioSpectrometry Workstation (PerSeptive Biosystems Inc., Framingham, MA) mass spectrometer equipped with a nitrogen laser emitting at $337 \mathrm{~nm}$. The instrument was operated in the linear mode at an accelerating voltage in the range $22000 \mathrm{~V}$. External calibration was performed with $\mathrm{C}_{60} /$ $\mathrm{C}_{70}$, and detection was performed by means of a linear detector and digitizing oscilloscope operating at $500 \mathrm{MHz}$. Sample solutions with $\sim 10 \mathrm{mg} / \mathrm{mL}$ in THF were used, and the matrix was 3,5-dihydroxybenzoic acid or 5-chlorosalicylic acid in THF $(10 \mathrm{mg} / \mathrm{mL})$. A solution of silver(I) trifluoroacetate in THF was added in some cases to the sample in order to improve the peak resolution. The sample solution $(0.2 \mu \mathrm{L})$ and the matrix solution $(0.2 \mu \mathrm{L})$ were combined and placed on a gold MALDI target and analyzed after evaporation of the solvents.

$\left.\left[\mathbf{P t I}\left(\mathbf{P P h}_{3}\right)_{2} \mathbf{2} \mathbf{N C}(\mathbf{B r}) \mathbf{N}\right)\right] \mathbf{2}$. A solution of $\mathbf{1}(0.18 \mathrm{~g}, 0.45 \mathrm{mmol})$ and $\left[\mathrm{Pt}\left(\mathrm{PPh}_{3}\right)_{4}\right](0.56 \mathrm{~g}, 0.45 \mathrm{mmol})$ in toluene $(50 \mathrm{~mL})$ was refluxed for $20 \mathrm{~h}$. Subsequently, all volatiles were evaporated and the residual solid was dissolved in $\mathrm{CH}_{2} \mathrm{Cl}_{2}(5 \mathrm{~mL})$. Hexane $(60 \mathrm{~mL})$ was added, and a white solid precipitated. This precipitate was collected and washed two more times with hexane to give $\mathbf{2}$ as a white powder $(0.37 \mathrm{~g}, 74 \%)$. ${ }^{13} \mathrm{C}$ NMR $\left(75 \mathrm{MHz}, \mathrm{CD}_{2} \mathrm{Cl}_{2}\right) \delta=45.6\left(\mathrm{~N}\left(\mathrm{CH}_{3}\right)_{2}\right), 64.5\left(\mathrm{CH}_{2}\right), 121.9$ $(C), 128.2\left(\mathrm{t},{ }^{3} J_{\mathrm{PC}}=4.3 \mathrm{~Hz}, C_{\mathrm{meta}}, \mathrm{PPh}_{3}\right), 130.5\left(C_{\text {para }}, \mathrm{PPh}_{3}\right), 130.6$, $131.8\left(\mathrm{t},{ }^{3} J_{\mathrm{PC}}=28.7 \mathrm{~Hz}, C_{\mathrm{ipss}}, \mathrm{PPh}_{3}\right), 135.5\left(\mathrm{t},{ }^{3} J_{\mathrm{PC}}=6.1 \mathrm{~Hz}, C_{\text {ortho, }}\right.$, $\left.\mathrm{PPh}_{3}\right), 137.5,138.6\left(C_{\mathrm{ipso}}\right)$. MS (MALDI-TOF): $\mathrm{m} / z 1115.7[\mathrm{M}]^{+}(\mathrm{calcd}$ 1115.1), $988.5[\mathrm{M}-\mathrm{I}]^{+}$(calcd 988.2). Anal. Calcd for $\mathrm{C}_{48} \mathrm{H}_{48} \mathrm{BrIN}_{2} \mathrm{P}_{2-}$ $\mathrm{Pt} \cdot 0.5 \mathrm{CH}_{2} \mathrm{Cl}_{2}$ (1159.2): C, 50.25; H, 4.26; N, 2.42. Found: $\mathrm{C}, 50.66$; $\mathrm{H}, 3.88 ; \mathrm{N}, 2.12$.

[PtBr(NCN-I-4)] 3a. A mixture of $\mathbf{1}(1.00 \mathrm{~g}, 2.52 \mathrm{mmol})$ and [Pt$\left.(\text { tol- } 4)_{2}\left(\mathrm{SEt}_{2}\right)\right]_{2}(1.17 \mathrm{~g}, 1.26 \mathrm{mmol})$ in dry benzene $(50 \mathrm{~mL})$ was stirred at reflux temperature for $2 \mathrm{~h}$. The slightly yellow solution was allowed to cool to room temperature, all volatiles were removed in vacuo, and the crude product was recrystallized from benzene/pentane to afford $1.17 \mathrm{~g}(78 \%)$ of $\mathbf{3 a}$ as colorless needles. ${ }^{13} \mathrm{C}$ NMR $\left(75 \mathrm{MHz}, \mathrm{CDCl}_{3}\right)$ $\delta=55.6\left(\mathrm{~N}\left(\mathrm{CH}_{3}\right)_{2}\right), 76.7\left(\mathrm{CH}_{2}\right), 86.1\left(C_{\mathrm{para}}\right), 128.1\left(^{3} J_{\mathrm{PtC}}=37.4 \mathrm{~Hz}\right.$, $\left.C_{\text {meta }}\right), 145.7\left(C_{\text {ortho }}\right), 146.1\left(C_{\text {ipso }}\right)$. MS (MALDI-TOF): $m / z 591.4[\mathrm{M}]^{+}$ (calcd 590.9), $510.4[\mathrm{M}-\mathrm{Br}]^{+}$(calcd 512.0). Anal. Calcd for $\mathrm{C}_{12} \mathrm{H}_{18-}$ $\mathrm{BrIN}_{2} \mathrm{Pt}$ (590.93): C, 24.34; H, 3.06; N, 4.73. Found: C, 24.26; H, $3.15 ; \mathrm{N}, 4.75$.

[PtI(NCN-I-4)] 3b. A solution of 3a $(0.54 \mathrm{~g}, 0.92 \mathrm{mmol})$ and $\mathrm{AgBF}_{4}$ $(0.20 \mathrm{~g}, 1.01 \mathrm{mmol})$ in acetone $/ \mathrm{CH}_{2} \mathrm{Cl}_{2}(1: 1,30 \mathrm{~mL})$ was stirred for 30 min. The suspension formed was filtered over Celite to yield a yellowish filtrate. The solvent was removed from the filtrate in vacuo, and the residue obtained was dissolved in acetone $(25 \mathrm{~mL})$. To this solution was added $\mathrm{NaI}(2.00 \mathrm{~g}, 13.3 \mathrm{mmol})$, and the resulting suspension was stirred overnight. After this time solvent was removed in vacuo, and the crude product was dissolved in $\mathrm{CH}_{2} \mathrm{Cl}_{2}(25 \mathrm{~mL})$ and washed with water $(10 \mathrm{~mL})$ and brine $(10 \mathrm{~mL})$. The organic layer was dried over $\mathrm{MgSO}_{4}$ and evaporated to dryness to afford $0.54 \mathrm{~g}(93 \%)$ of $\mathbf{3 b}$ as an yellow powder. ${ }^{13} \mathrm{C} \mathrm{NMR}\left(75 \mathrm{MHz}, \mathrm{CDCl}_{3}\right) \delta=56.3\left(\mathrm{~N}_{(}\left(\mathrm{CH}_{3}\right)_{2}\right), 76.1$ $\left(\mathrm{CH}_{2}\right), 86.3$ (ArI), 128.1 ( $\left.C_{\text {meta }}\right), 145.8$ ( $\left.C_{\text {ortho }}\right), 149.1\left(C_{\text {ipso }}\right)$. MS (MALDI-TOF): $m / z 511.5[\mathrm{M}-\mathrm{I}]^{+}(\operatorname{calcd} 512.0), 317.8[\mathrm{M}-\mathrm{PtI}]^{+}$

(39) Steele, B. R.; Vrieze, K. Transition Met. Chem. 1977, 2, 140-144.

(40) Komiya, S. Synthesis of Organometallic Compounds; Wiley: Chichester, U.K., 1997. 
(calcd 317.0). Anal. Calcd for $\mathrm{C}_{12} \mathrm{H}_{18} \mathrm{I}_{2} \mathrm{~N}_{2} \mathrm{Pt}$ (639.18): C, 22.55; H, 2.84; N, 4.38. Found: C, 22.65; H, 2.88; N, 4.32.

[PdBr(NCN-I-4)] 4a. Solid $\left[\mathrm{Pd}_{2}\left(\mathrm{dba}_{3} \cdot{ }_{3} \cdot \mathrm{CHCl}_{3}\right](2.71 \mathrm{~g}, 1.58 \mathrm{mmol})\right.$ was added to a stirred solution of $\mathbf{1}(1.25 \mathrm{~g}, 3.15 \mathrm{mmol})$ in toluene (50 $\mathrm{mL}$ ) at $-80^{\circ} \mathrm{C}$. The resulting solution was allowed to warm to room temperature and stirred overnight. The reaction mixture was filtered through Celite and the solvent was removed under reduced pressure. The solid residue was dissolved in wet acetone $(20 \mathrm{~mL}), \mathrm{AgBF}_{4}(0.61$ $\mathrm{g}, 3.15 \mathrm{mmol}$ ) was added, and the suspension was stirred for $1 \mathrm{~h}$. After this time, the resulting cloudy solution was filtered through Celite, and the solvent was concentrated to ca. $5 \mathrm{~mL}$. Then $\mathrm{Et}_{2} \mathrm{O}$ was added $(20$ $\mathrm{mL}$ ), which resulted in the formation of a precipitate that was collected and purified by repetitive washing with $\mathrm{Et}_{2} \mathrm{O}$. The solid was dissolved in $\mathrm{CH}_{2} \mathrm{Cl}_{2}(20 \mathrm{~mL})$ and stirred with an excess of $\mathrm{LiBr}(0.33 \mathrm{~g}, 3.80$ $\mathrm{mmol}$ ) for $2 \mathrm{~h}$. The suspension was subsequently filtered over Celite. The filtrate was washed with water and brine, dried over $\mathrm{MgSO}_{4}$, and evaporated to dryness to give $\mathbf{4 a}$ as an yellow solid (yield $0.37 \mathrm{~g}, 25 \%$ ). ${ }^{13} \mathrm{C}$ NMR $\left(75 \mathrm{MHz}, \mathrm{C}_{6} \mathrm{D}_{6}\right) \delta=53.3\left(\mathrm{~N}\left(\mathrm{CH}_{3}\right)_{2}\right), 73.7\left(\mathrm{CH}_{2}\right), 88.4\left(C_{\text {para }}\right)$, $128.6\left(C_{\text {meta }}\right), 147.8\left(C_{\text {ortho }}\right), 158.1\left(C_{\text {ipso }}\right)$. MS (MALDI-TOF): $m / z 531.4$ $[(\mathrm{M}-\mathrm{Br})+\mathrm{Ag}]^{+}\left(\right.$calcd 529.8), $423.8[\mathrm{M}-\mathrm{Br}]^{+}($calcd 423.0).

$\left.\left[\mathbf{P d I}\left(\mathbf{P P h}_{3}\right)_{2} \mathbf{( N C}(\mathbf{B r}) \mathbf{N}\right)\right]$ 5. A solution of $\mathbf{1}(1.06 \mathrm{~g}, 2.67 \mathrm{mmol})$ and $\left[\mathrm{Pd}\left(\mathrm{PPh}_{3}\right)_{4}\right](2.74 \mathrm{~g}, 2.67 \mathrm{mmol})$ in toluene $(75 \mathrm{~mL})$ was stirred at 50 ${ }^{\circ} \mathrm{C}$ for 1 day. Subsequently, all volatiles were evaporated and the residual solid was dissolved in $\mathrm{CH}_{2} \mathrm{Cl}_{2}(10 \mathrm{~mL})$. Hexane $(60 \mathrm{~mL})$ was then added, and a yellow solid precipitated. This precipitate was collected and washed several times with hot hexane to give $\mathbf{5}$ as a yellow powder $(2.00 \mathrm{~g}, 73 \%) .{ }^{13} \mathrm{C} \mathrm{NMR}\left(75 \mathrm{MHz}, \mathrm{CD}_{2} \mathrm{Cl}_{2}\right) \delta=45.4\left(\mathrm{NCH}_{3}\right)$, $64.3\left(\mathrm{ArCH}_{2}\right), 122.6\left(C_{\mathrm{para}}\right), 128.1\left(\mathrm{t},{ }^{3} \mathrm{~J}_{\mathrm{PC}}=5.1 \mathrm{~Hz}, C_{\text {meta }}, \mathrm{PPh}_{3}\right), 130.2$ $\left(C_{\text {para }}, \mathrm{PPh}_{3}\right), 132.2\left(\mathrm{t},{ }^{3} J_{\mathrm{PC}}=23.1 \mathrm{~Hz}, C_{\mathrm{ipso}}, \mathrm{PPh}_{3}\right), 135.2\left(\mathrm{t},{ }^{3} J_{\mathrm{PC}}=6.2\right.$ $\left.\mathrm{Hz}, C_{\text {ortho }}, \mathrm{PPh}_{3}\right), 137.1\left(C_{\text {meta }}\right), 137.5\left(C_{\text {ortho }}\right), 155.9\left(C_{\text {ipso }}\right)$. Anal. Calcd for $\mathrm{C}_{48} \mathrm{H}_{48} \mathrm{BrIN}{ }_{2} \mathrm{P}_{2} \mathrm{Pd} \cdot 0.5 \mathrm{CH}_{2} \mathrm{Cl}_{2}$ (1070.6): $\mathrm{C}, 54.41 ; \mathrm{H}, 4.61 ; \mathrm{N}, 2.62$; P, 5.79. Found: C, 54.52; H, 4.98; N, 2.20; P, 5.77.

[NC(Br)N-CHO-4] 7. To a solution of $\mathbf{1}(2.19 \mathrm{~g}, 5.52 \mathrm{mmol})$ in dry $\mathrm{Et}_{2} \mathrm{O}(30 \mathrm{~mL})$ was added dropwise $t$-BuLi $(6.2 \mathrm{~mL}, 1.7 \mathrm{M}$ in hexane, $10.5 \mathrm{mmol}$ ) at $-100{ }^{\circ} \mathrm{C}$. The solution was stirred for $10 \mathrm{~min}$ at low temperature and then treated with DMF (15 mL, large excess). After warming to room temperature, the mixture was stirred for $14 \mathrm{~h} . \mathrm{H}_{2} \mathrm{O}$ was added $(20 \mathrm{~mL})$, and stirring was continued for $1 \mathrm{~h}$. The mixture was diluted with $\mathrm{NaOH}(2 \mathrm{M}, 40 \mathrm{~mL})$ and extracted with $\mathrm{Et}_{2} \mathrm{O}(3 \times$ $50 \mathrm{~mL}$ ). The organic layers were combined, washed with brine, dried over $\mathrm{MgSO}_{4}$, and evaporated to dryness. The crude product was further purified by column chromatography $\left[\mathrm{Al}_{2} \mathrm{O}_{3}\left(4 \% \mathrm{NH}_{4} \mathrm{OH}\right)\right.$, pentane/ ethyl acetate, 3:1], yielding 7 as a yellowish oil (1.43 g, 87\%). ${ }^{1} \mathrm{H}$ NMR $\left(200 \mathrm{MHz}, \mathrm{CDCl}_{3}\right) \delta=2.33\left(\mathrm{~s}, 12 \mathrm{H}, \mathrm{NCH}_{3}\right), 3.60\left(\mathrm{~s}, 4 \mathrm{H}, \mathrm{CH}_{2}\right), 7.86$ (s, 2H, $\mathrm{ArH}$ ), 10.02 (s, CHO). ${ }^{13} \mathrm{C} \mathrm{NMR}\left(75 \mathrm{MHz}, \mathrm{CDCl}_{3}\right) \delta=45.7$ $\left(\mathrm{N}\left(\mathrm{CH}_{3}\right)_{2}\right), 63.7\left(\mathrm{CH}_{2}\right), 129.8,133.6,134.8,140.1,191.8(\mathrm{CHO})$. Anal. Calcd for $\mathrm{C}_{13} \mathrm{H}_{19} \mathrm{BrN}_{2} \mathrm{O}$ (298.07): C, 52.18; H, 6.40; N, 9.37. Found: C, 52.22; H, 7.07; N, 9.37.

[PtBr(NCN-CHO-4)] 8a. A mixture of 7 (200 mg, $0.67 \mathrm{mmol})$ and $\left[\mathrm{Pt}(\text { tol-4 })_{2}\left(\mathrm{SEt}_{2}\right)\right]_{2}(312 \mathrm{mg}, 0.67 \mathrm{mmol})$ was stirred for $3 \mathrm{~h}$ in benzene $(20 \mathrm{~mL})$ at reflux temperature. The yellowish solution was allowed to cool to room temperature, volatiles were removed, and the residue crystallized from $\mathrm{CH}_{2} \mathrm{Cl}_{2}$ /pentane to afford $\mathbf{8} \mathbf{a}$ as needle-shaped crystals $(0.25 \mathrm{~g}, 76 \%) .{ }^{1} \mathrm{H}$ NMR $\left(200 \mathrm{MHz}, \mathrm{CDCl}_{3}\right) \delta=3.14\left(\mathrm{~s}, 12 \mathrm{H},{ }^{3} J_{\mathrm{PHH}}=\right.$ $\left.38.7 \mathrm{~Hz}, \mathrm{~N}\left(\mathrm{CH}_{3}\right)_{2}\right), 4.08\left(\mathrm{~s}, 4 \mathrm{H},{ }^{3} \mathrm{~J}_{\mathrm{PtH}}=46.2 \mathrm{~Hz}, \mathrm{CH}_{2}\right), 7.34(\mathrm{~s}, 2 \mathrm{H}$, $\mathrm{ArH}), 9.85(\mathrm{~s}, 1 \mathrm{H}, \mathrm{CHO}) .{ }^{13} \mathrm{C}$ NMR $\left(75 \mathrm{MHz}, \mathrm{CDCl}_{3}\right) \delta=55.0$ $\left(\mathrm{N}\left(\mathrm{CH}_{3}\right)_{2}\right), 76.8\left(\mathrm{CH}_{2}\right), 121.3\left({ }^{3} J_{\mathrm{PtC}}=36 \mathrm{~Hz}, C_{\text {meta }}\right), 133.1\left(C_{\text {para }}\right), 144.1$ $\left({ }^{3} J_{\mathrm{PtC}}=77.3 \mathrm{~Hz}, C_{\text {ortho }}\right), 157.5\left(C_{\mathrm{ipso}}\right), 191.8(C \mathrm{HO})$. Anal. Calcd for $\mathrm{C}_{13} \mathrm{H}_{19} \mathrm{BrN}_{2} \mathrm{OPt}$ (493.03): C, 31.59; H, 3.87; N, 5.67. Found: C, 31.80; $\mathrm{H}, 3.95 ; \mathrm{N}, 5.59$.

[PtI(NCN-CHO-4)] 8b. To a solution of 3a $(0.38 \mathrm{~g}, 0.59 \mathrm{mmol})$ in dry THF $(30 \mathrm{~mL})$ was added dropwise $t$-BuLi $(0.78 \mathrm{~mL}, 1.5 \mathrm{M}$ in hexane, $1.18 \mathrm{mmol}$ ) at $-100{ }^{\circ} \mathrm{C}$. The solution was stirred for $5 \mathrm{~min}$ and subsequently treated with DMF (1.5 mL, large excess). After being stirred for $15 \mathrm{~min}$, the reaction mixture was quenched with a saturated aqueous solution of $\mathrm{NH}_{4} \mathrm{Cl}(5 \mathrm{~mL})$. The resulting suspension was allowed to warm to room temperature and all volatiles were removed in vacuo. The residue was dissolved in $\mathrm{CH}_{2} \mathrm{Cl}_{2}$, washed with brine, dried over $\mathrm{MgSO}_{4}$, and evaporated to dryness. The resulting mixture was dissolved in acetone and $\mathrm{AgBF}_{4}(0.13 \mathrm{~g}, 0.65 \mathrm{mmol})$ was added. The suspension formed was stirred for $30 \mathrm{~min}$ and then filtered over Celite. The solvent from the filtrate was removed in vacuo and the residue obtained was dissolved in acetone $(30 \mathrm{~mL})$. To this solution was added $\mathrm{NaI}(0.89 \mathrm{~g}, 5.90 \mathrm{mmol})$, and the resulting suspension was stirred overnight. After this time solvent was removed in vacuo, and the crude product was dissolved in $\mathrm{CH}_{2} \mathrm{Cl}_{2}(30 \mathrm{~mL})$ and washed with water $(10 \mathrm{~mL})$ and brine $(10 \mathrm{~mL})$. The organic layer was dried over $\mathrm{MgSO}_{4}$ and evaporated to dryness to afford $0.23 \mathrm{~g}$ of $\mathbf{8 b}(74 \%)$ as a yellow powder. ${ }^{1} \mathrm{H}$ NMR $\left(300 \mathrm{MHz}, \mathrm{CDCl}_{3}\right) \delta=3.21\left(\mathrm{~s}, 12 \mathrm{H},{ }^{3} J_{\mathrm{PtH}}\right.$ $\left.=37.5 \mathrm{~Hz}, \mathrm{~N}\left(\mathrm{CH}_{3}\right)_{2}\right), 4.10\left(\mathrm{~s}, 4 \mathrm{H},{ }^{3} J_{\mathrm{PtH}}=44.1 \mathrm{~Hz}, \mathrm{CH}_{2}\right), 7.36(\mathrm{~s}, 2 \mathrm{H}$, $\mathrm{ArH}), 9.88(\mathrm{~s}, 1 \mathrm{H}, \mathrm{CHO}) .{ }^{13} \mathrm{C}$ NMR $\left(75 \mathrm{MHz}, \mathrm{CDCl}_{3}\right) \delta=56.4$ $\left(\mathrm{N}\left(\mathrm{CH}_{3}\right)_{2}\right), 76.3\left(\mathrm{CH}_{2}\right), 121.5\left({ }^{3} J_{\mathrm{PtC}}=36 \mathrm{~Hz}, C_{\text {meta }}\right), 133.1\left(C_{\mathrm{para}}\right), 144.3$ $\left({ }^{3} J_{\mathrm{PtC}}=77.3 \mathrm{~Hz}, C_{\text {ortho }}\right), 163.0\left(C_{\mathrm{ipso}}\right), 191.8(C \mathrm{HO})$. Anal. Calcd for $\mathrm{C}_{13} \mathrm{H}_{19} \mathrm{IN}_{2} \mathrm{OPt}$ (541.29): C, 28.85; H, 3.54; N, 5.18. Found: C, 29.08; $\mathrm{H}, 3.59$; N, 5.12 .

[PdBr(NCN-CHO-4)] 9. A solution of $7(0.19 \mathrm{~g}, 0.64 \mathrm{mmol})$ and $\left[\mathrm{Pd}_{2}(\mathrm{dba})_{3} \cdot \mathrm{CHCl}_{3}\right](0.36 \mathrm{~g}, 0.35 \mathrm{mmol})$ in dry benzene $(20 \mathrm{~mL})$ was refluxed for $3 \mathrm{~h}$. After this time the reaction mixture was cooled to room temperature and filtered through Celite. Subsequently, all volatiles were evaporated and the residual solid was dissolved in $\mathrm{CH}_{2} \mathrm{Cl}_{2}(5 \mathrm{~mL})$. Hexane $(50 \mathrm{~mL})$ was then added and a yellow solid precipitated. This precipitate was collected and washed several times with pentane to give 9 as a yellow powder $(0.17 \mathrm{~g}, 64 \%) .{ }^{1} \mathrm{H}$ NMR $\left(200 \mathrm{MHz}, \mathrm{CDCl}_{3}\right) \delta=$ 2.99 (s, 12H, N( $\left.\left.\mathrm{CH}_{3}\right)_{2}\right), 4.07$ (s, 4H, $\left.\mathrm{CH}_{2}\right), 7.31$ (s, 2H, $\left.\mathrm{ArH}\right), 9.85$ (s, $1 \mathrm{H}, \mathrm{CHO}) .{ }^{13} \mathrm{C}$ NMR $\left(75 \mathrm{MHz}, \mathrm{CDCl}_{3}\right) \delta=53.7\left(\mathrm{~N}\left(\mathrm{CH}_{3}\right)_{2}\right), 74.1$ $\left(\mathrm{CH}_{2}\right), 121.4\left(C_{\text {meta }}\right), 128.9\left(C_{\text {para }}\right), 134.0\left(C_{\text {ortho }}\right), 145.7\left(C_{\text {ipso }}\right), 191.6$ (CHO). MS (MALDI-TOF): $\mathrm{m} / \mathrm{z} 323.3[\mathrm{M}-\mathrm{Br}]^{+}$(calcd 325.0), 217.8 $[\mathrm{M}-\mathrm{PdBr}]^{+}$(calcd 219.1). Anal. Calcd for $\mathrm{C}_{13} \mathrm{H}_{19} \mathrm{BrN}_{2} \mathrm{OPd} \cdot 0.5 \mathrm{H}_{2} \mathrm{O}$ (414.6): C, 37.66; H, 4.86; N, 6.76. Found: C, 37.86; H, 4.50; N, 6.50 .

[PtCl(NCN-OH-4)] 11. Complex $10(1.65 \mathrm{~g}, 3.0 \mathrm{mmol})$ was suspended in a mixture of acetone $(40 \mathrm{~mL})$ and $\mathrm{HCl}(2 \mathrm{M}, 10 \mathrm{~mL})$ and stirred in air at $55{ }^{\circ} \mathrm{C}$ for $6 \mathrm{~h}$. During this time a precipitate formed, which was collected, washed with portions of $\mathrm{Et}_{2} \mathrm{O}(3 \times 40 \mathrm{~mL})$, and dried in vacuo to leave $\mathbf{1 1}$ as a white solid $(0.57 \mathrm{~g}, 78 \%)$. All analytical data were consistent with those reported in the literature. ${ }^{19 \mathrm{~d}}$

[PtBr(NCN-CH $\left.\left.\mathbf{C H}_{2} \mathrm{OH}-4\right)\right]$ 14. To a cooled $\left(10{ }^{\circ} \mathrm{C}\right)$ suspension of $8 \mathbf{a}$ $(0.15 \mathrm{~g}, 0.27 \mathrm{mmol})$ in $\mathrm{MeOH}(15 \mathrm{~mL})$ and $\mathrm{AcOH}(17 \mathrm{mg}, 96 \mu \mathrm{L}$, $0.28 \mathrm{mmol}$ ) were added portions of $\mathrm{NaBH}_{3} \mathrm{CN}$ (in total $34 \mathrm{mg}, 0.54$ $\mathrm{mmol})$. The reaction mixture was allowed to warm to room temperature and stirred for an additional $2 \mathrm{~h}$. All volatiles were removed in vacuo, and the residue was diluted in $\mathrm{NaOH}(2 \mathrm{M}, 4 \mathrm{~mL})$ and extracted with EtOAc $(3 \times 10 \mathrm{~mL})$. The combined organic extracts were dried over $\mathrm{MgSO}_{4}$ and concentrated to give 14 (88 mg, 59\%). ${ }^{1} \mathrm{H} \mathrm{NMR}(200 \mathrm{MHz}$, $\left.\mathrm{CDCl}_{3}\right) \delta=1.85($ br s, $1 \mathrm{H}, \mathrm{OH}), 3.10\left(\mathrm{~s}, 12 \mathrm{H},{ }^{3} J_{\mathrm{PtH}}=38.4 \mathrm{~Hz}\right.$, $\left.\mathrm{N}\left(\mathrm{CH}_{3}\right)_{2}\right), 4.00\left(\mathrm{~s}, 4 \mathrm{H},{ }^{3} J_{\mathrm{PtH}}=46.4 \mathrm{~Hz}, \mathrm{CH}_{2}\right), 4.50\left(\mathrm{~s}, 2 \mathrm{H}, \mathrm{CH}_{2} \mathrm{OH}\right)$, $6.83(\mathrm{~s}, 2 \mathrm{H}, \mathrm{ArH}) .{ }^{13} \mathrm{C}$ NMR $\left(50 \mathrm{MHz}, \mathrm{CDCl}_{3}\right) \delta=55.0\left(\mathrm{~N}\left(\mathrm{CH}_{3}\right)_{2}\right)$, $66.0\left(\mathrm{CH}_{2} \mathrm{OH}\right), 77.3\left(\mathrm{CH}_{2}\right), 118.7\left(C_{\text {meta }}\right), 124.7\left(C_{\mathrm{para}}\right), 136.1\left({ }^{3} J_{\mathrm{PtC}}=\right.$ $\left.77.3 \mathrm{~Hz}, C_{\text {ortho}}\right), 143.5\left(C_{\mathrm{ipso}}\right)$. MS (MALDI-TOF): $\mathrm{m} / \mathrm{z} 415.2$ [M $\mathrm{Br}]^{+}$(calcd 414.0). Anal. Calcd for $\mathrm{C}_{13} \mathrm{H}_{19} \mathrm{BrN}_{2} \mathrm{OPt}$ (493.03): C, 31.46; H, 4.26; N, 5.64. Found: C, 31.55; H, 4.26; N, 5.57.

[PtBr(NCN- $\left.\left.\left\{\mathrm{CH}_{2}-\mathrm{L}-\mathrm{Val}-\mathrm{OMe}\right\}-4\right)\right]$ 15. A mixture of $8 \mathbf{8}(110 \mathrm{mg}$, $0.23 \mathrm{mmol})$, L-valine methyl ester hydrochloride (75 $\mathrm{mg}, 0.45 \mathrm{mmol}$ ), triethylamine $(0.06 \mathrm{~mL}, 0.45 \mathrm{mmol})$, and $\mathrm{MgSO}_{4}(1.0 \mathrm{~g})$ was stirred in $\mathrm{CH}_{2} \mathrm{Cl}_{2}(10 \mathrm{~mL})$ at room temperature for 2 days. Subsequently, all solids were filtered off and the filtrate was evaporated under reduced pressure. The residue was dissolved in $\mathrm{MeOH}(10 \mathrm{~mL})$ and $\mathrm{AcOH}(17 \mathrm{mg}, 96$ $\mu \mathrm{L}, 0.28 \mathrm{mmol})$. This solution was kept below $10{ }^{\circ} \mathrm{C}$ while portions of $\mathrm{NaBH}_{3} \mathrm{CN}$ (27.9 mg, $\left.0.44 \mathrm{mmol}\right)$ were added. The reaction mixture was allowed to warm to room temperature and stirred for an additional 
Table 4. Crystallographic Data for Compounds 2, 3a, 19, 20, and 24

\begin{tabular}{|c|c|c|c|c|c|}
\hline & 2 & 3a & 19 & 20 & 24 \\
\hline formula & $\mathrm{C}_{48} \mathrm{H}_{48} \mathrm{BrIN}_{2} \mathrm{P}_{2} \mathrm{Pt} \cdot 0.5\left(\mathrm{CH}_{2} \mathrm{Cl}_{2}\right)$ & $\mathrm{C}_{12} \mathrm{H}_{18} \mathrm{BrIN}_{2} \mathrm{Pt}$ & $\mathrm{C}_{48} \mathrm{H}_{48} \mathrm{I}_{2} \mathrm{~N}_{2} \mathrm{P}_{2} \mathrm{Pt} \bullet 1.8\left(\mathrm{CH}_{2} \mathrm{Cl}_{2}\right)$ & $\mathrm{C}_{48} \mathrm{H}_{48} \mathrm{I}_{2} \mathrm{~N}_{2} \mathrm{P}_{2} \mathrm{Pt}_{2} \cdot \mathrm{C}_{6} \mathrm{H}_{6}$ & $\mathrm{C}_{15} \mathrm{H}_{27} \mathrm{IN}_{2} \mathrm{PtSi}$ \\
\hline fw & 1159.19 & 592.16 & 1316.58 & 1436.91 & 585.47 \\
\hline $\begin{array}{l}\text { crystal size }\left[\mathrm{mm}^{3}\right] \\
\text { crystal color }\end{array}$ & $\begin{array}{l}0.34 \times 0.16 \times 0.04 \\
\text { colorless }\end{array}$ & $\begin{array}{l}0.50 \times 0.30 \times 0.15 \\
\text { colorless }\end{array}$ & $\begin{array}{l}0.48 \times 0.36 \times 0.12 \\
\text { colorless }\end{array}$ & $\begin{array}{l}0.36 \times 0.30 \times 0.12 \\
\text { yellowish }\end{array}$ & $\begin{array}{l}0.40 \times 0.25 \times 0.16 \\
\text { colorless }\end{array}$ \\
\hline diffractometer & Nonius KappaCCD & Enraf-Nonius CAD4T & Nonium KappaCCD & Nonium KappaCCD & Enraf-Nonius CAD4T \\
\hline$\lambda[\AA]$ & 0.71073 & 0.71073 & 0.71073 & 0.71073 & 0.71073 \\
\hline temperature $[\mathrm{K}]$ & $150(2)$ & $150(2)$ & $150(2)$ & $150(2)$ & $150(2)$ \\
\hline crystal system & triclinic & monoclinic & monoclinic & orthorhombic & monoclinic \\
\hline space group & $P \overline{1}($ no. 2$)$ & $P 2{ }_{1} / \mathrm{c}$ (no. 14$)$ & $P 2_{1} / \mathrm{c}$ (no. 14 ) & Pnma (no. 62) & $P 2_{1} / \mathrm{c}$ (no. 14$)$ \\
\hline$a[\AA]$ & $12.0481(1)$ & $10.7151(13)$ & $15.4841(1)$ & 23.794(3) & $13.6334(15)$ \\
\hline$b[\AA]$ & 13.9921(1) & $7.3901(5)$ & $21.1002(2)$ & $16.816(3)$ & $14.1668(19)$ \\
\hline$c[\AA]$ & $14.2119(2)$ & $21.018(3)$ & $21.8256(2)$ & $12.502(3)$ & $10.1738(8)$ \\
\hline$\alpha[\mathrm{deg}]$ & $88.5840(4)$ & 90 & 90 & 90 & 90 \\
\hline$\beta$ [deg] & $83.4641(4)$ & 114.673(9) & $133.6230(3)$ & 90 & $100.739(8)$ \\
\hline$\gamma[\mathrm{deg}]$ & $84.0046(5)$ & 90 & 90 & 90 & 90 \\
\hline$V\left[\AA^{3}\right]$ & 2367.03(4) & $1512.4(3)$ & $5161.95(8)$ & $5002.3(16)$ & 1930.6(4) \\
\hline $\mathrm{Z}$ & 2 & 4 & 4 & 4 & 4 \\
\hline$D_{\text {calc }}\left[\mathrm{g} / \mathrm{cm}^{3}\right]$ & 1.626 & 2.601 & 1.694 & 1.908 & 2.014 \\
\hline$\mu\left[\mathrm{mm}^{-1}\right]$ & 4.618 & 13.943 & 4.197 & 6.923 & 8.923 \\
\hline $\sin (\theta / \lambda) \max \left[\AA^{-1}\right]$ & 0.65 & 0.65 & 0.65 & 0.65 & 0.65 \\
\hline abs. correction & analytical & DELABS & analytical & analytical & DELABS \\
\hline transm range & $0.24-0.81$ & $0.10-0.56$ & $0.27-0.67$ & $0.20-0.57$ & $0.26-0.71$ \\
\hline refl meas/unique & 44 077/10 841 & $7127 / 3466$ & $69290 / 11820$ & $67537 / 5943$ & $9301 / 4399$ \\
\hline parameters & 559 & 158 & 563 & 325 & 188 \\
\hline restraints & 68 & 0 & 16 & 24 & 0 \\
\hline$R 1$ (obs/all refl) & $0.0339 / 0.0430$ & $0.0432 / 0.0547$ & $0.0311 / 0.0439$ & $0.0260 / 0.0419$ & $0.0383 / 0.0520$ \\
\hline$w R 2$ (obs/all refl) & $0.0913 / 0.0955$ & $0.0986 / 0.1034$ & $0.0728 / 0.0773$ & $0.0527 / 0.0596$ & $0.0833 / 0.0885$ \\
\hline GoF & 1.042 & 1.062 & 1.034 & 1.063 & 1.022 \\
\hline res. density $\left[\mathrm{e} / \AA^{3}\right]$ & $-1.74 / 1.18$ & $-2.30 / 2.58$ & $-1.10 / 1.91$ & $-1.20 / 1.05$ & $-1.70 / 2.06$ \\
\hline
\end{tabular}

$2 \mathrm{~h}$. All volatiles were then removed in vacuo, and the residue was extracted with $\mathrm{NaOH}(2 \mathrm{M}, 20 \mathrm{~mL})$ and $\mathrm{CH}_{2} \mathrm{Cl}_{2}(3 \times 20 \mathrm{~mL})$. The combined organic layers were washed with brine, dried over $\mathrm{MgSO}_{4}$, and concentrated. The resulting oil was purified by column chromatography $\left(\mathrm{SiO}_{2}\right.$, hexane $/ \mathrm{CH}_{2} \mathrm{Cl}_{2} /$ acetone) to give $\mathbf{1 4}$ as a yellowish solid (85 mg, 64\%). Analytical data are consistent with those reported in the literature. ${ }^{23}$

[PtBr(NCN-C $\left.\left.\equiv \mathrm{CSiMe}_{3}-4\right)\right]$ 16. To a suspension of $\mathbf{3 a}(0.12 \mathrm{~g}, 0.2$ $\mathrm{mmol}), \mathrm{CuI}(2 \mathrm{mg}, 0.01 \mathrm{mmol})$, and $\left[\mathrm{PdCl}_{2}\left(\mathrm{PPh}_{3}\right)_{2}\right](2 \mathrm{mg}, 0.01 \mathrm{mmol})$ in $\mathrm{Et}_{2} \mathrm{NH}(10 \mathrm{~mL})$ was added trimethylsilylacetylene $(21 \mathrm{mg}, 31 \mu \mathrm{L}$, $0.22 \mathrm{mmol}$ ). The reaction mixture was stirred at room temperature for $16 \mathrm{~h}$ and subsequently evaporated to dryness. The residue was redissolved in $\mathrm{CH}_{2} \mathrm{Cl}_{2}(10 \mathrm{~mL})$ and washed with $\mathrm{AcOH}(1 \mathrm{M})$, brine, and water. After being dried over $\mathrm{MgSO}_{4}$, the solution was concentrated to $1 \mathrm{~mL}$ and pentane $(15 \mathrm{~mL})$ was added, which caused the precipitation of $\mathbf{1 6}$ as an off-white solid $(68 \mathrm{mg}, 60 \%) .{ }^{1} \mathrm{H}$ NMR $\left(300 \mathrm{MHz}, \mathrm{CDCl}_{3}\right)$ $\delta=0.19\left(\mathrm{~s}, 9 \mathrm{H}, \mathrm{SiMe}_{3}\right), 3.14\left(\mathrm{~s}, 12 \mathrm{H},{ }^{3} J_{\mathrm{PtH}}=40.2 \mathrm{~Hz}, \mathrm{~N}\left(\mathrm{CH}_{3}\right)_{2}\right)$, $3.96\left(\mathrm{~s}, 4 \mathrm{H},{ }^{3} J_{\mathrm{PtH}}=44.7 \mathrm{~Hz}, \mathrm{CH}_{2}\right), 6.92(\mathrm{~s}, 2 \mathrm{H}, \mathrm{ArH})$. For an alternative preparation of such complexes, see ref 28.

$\left[\mathrm{PdBr}\left(\mathrm{NCN}-\mathrm{C} \equiv \mathrm{CSiMe}_{3}-4\right)\right] \mathbf{1 7}$. This complex was obtained by a procedure similar to the one applied for the preparation of $\mathbf{1 6}$, starting from $4 \mathbf{a}$ (64 mg, $0.12 \mathrm{mmol}), \mathrm{CuI}(2 \mathrm{mg}, 0.06 \mathrm{mmol}),\left[\mathrm{PdCl}_{2}\left(\mathrm{PPh}_{3}\right)_{2}\right]$ (5 mg, $0.06 \mathrm{mmol}$ ), and trimethylsilylacetylene $(14 \mathrm{mg}, 0.14$ mmol).Yield: $40 \mathrm{mg}(66 \%) .{ }^{1} \mathrm{H}$ NMR $\left(300 \mathrm{MHz}, \mathrm{C}_{6} \mathrm{D}_{6}\right) \delta=0.30(\mathrm{~s}$, 9H, $\left.\mathrm{SiMe}_{3}\right), 2.55$ (s, 12H, N( $\left.\left.\mathrm{CH}_{3}\right)_{2}\right), 3.14$ (s, 4H, CH $\mathrm{CH}_{2}, 6.82(\mathrm{~s}, 2 \mathrm{H}$,

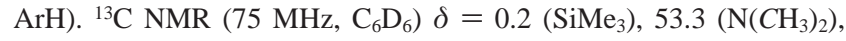
$74.0\left(\mathrm{CH}_{2}\right), 92.9\left(\mathrm{ArC} \equiv C \mathrm{SiMe}_{3}\right), 107.2\left(\mathrm{ArC} \equiv \mathrm{CSiMe}_{3}\right), 119.3\left(C_{\mathrm{para}}\right)$, $123.4\left(C_{\text {meta }}\right), 145.6\left(C_{\text {ortho }}\right), 160.8\left(C_{\text {ipso }}\right)$. MS (MALDI-TOF): $m / z 393.0$ $[\mathrm{M}-\mathrm{Br}]^{+}$(calcd 393.1). Anal. Calcd for $\mathrm{C}_{17} \mathrm{H}_{27} \mathrm{BrN}_{2} \mathrm{SiPd}$ (473.8): C, 43.09; H, 5.74; N, 5.91. Found: C, 42.81; H, 5.63; N, 5.71.

$\left.\left[\mathrm{NC}(\mathrm{Br}) \mathrm{N}-\mathrm{C} \equiv \mathrm{CSiMe}_{3}-\mathbf{4}\right)\right] \mathbf{1 8}$. This compound was obtained by a procedure similar to the one applied for the preparation of $\mathbf{1 6}$, starting from 5 (44 mg, $0.04 \mathrm{mmol})$ and trimethylsilylacetylene $(7 \mathrm{mg}, 0.08$ mmol).Yield: $9 \mathrm{mg}(62 \%) .{ }^{1} \mathrm{H} \mathrm{NMR}\left(200 \mathrm{MHz},\left(\mathrm{CD}_{3}\right)_{2} \mathrm{CO}\right): \delta=0.24$ (s, 9H, $\left.\mathrm{SiMe}_{3}\right), 2.17$ (s, 12H, N(CH$\left.)_{2}\right), 3.37$ (s, 4H, $\left.\mathrm{CH}_{2}\right), 7.30$ (s, $2 \mathrm{H}$, $\mathrm{ArH}) .{ }^{13} \mathrm{C}$ NMR $\left(50 \mathrm{MHz},\left(\mathrm{CD}_{3}\right)_{2} \mathrm{CO}\right) \delta=-0.4\left(\mathrm{SiMe}_{3}\right), 45.0$
$\left(\mathrm{N}\left(\mathrm{CH}_{3}\right)_{2}\right), 63.6\left(\mathrm{CH}_{2}\right), 93.2\left(\mathrm{ArC} \equiv C \mathrm{SiMe}_{3}\right), 105.8\left(\mathrm{ArC} \equiv \mathrm{CSiMe}_{3}\right)$, $122.9(C), 129.9(C), 130.8,140.2(C) .^{30}$

[PtI $\left.\left(\eta^{1}-C-C_{6} \mathrm{H}_{3}\left\{\mathrm{CH}_{2} \mathrm{NMe}_{2}\right\}_{2}-2,6-\mathrm{I}-4\right)\left(\mathrm{PPh}_{3}\right)_{2}\right]$ 19. Addition of $\mathrm{PPh}_{3}$ $(0.33 \mathrm{~g}, 1.26 \mathrm{mmol})$ to a solution of $\mathbf{3 b}(0.38 \mathrm{~g}, 0.60 \mathrm{mmol})$ in $\mathrm{C}_{6} \mathrm{H}_{6}$ $(20 \mathrm{~mL})$ afforded, after stirring overnight and removal of all volatiles, the crude title product. Purification was achieved by repeated crystallization of 19 from $\mathrm{CH}_{2} \mathrm{Cl}_{2}$ /pentane. Yield: $0.53 \mathrm{~g}$ (99\%). Crystals suitable for $\mathrm{X}$-ray structure determination were grown by recrystallization from $\mathrm{CH}_{2} \mathrm{Cl}_{2} /$ pentane. ${ }^{13} \mathrm{C}$ NMR $\left(75 \mathrm{MHz}, \mathrm{CDCl}_{3}\right) \delta=45.5$ $\left(\mathrm{NCH}_{3}\right), 70.0\left(\mathrm{CH}_{2}\right), 89.1\left(C_{\text {para }}\right), 127.9-136.1\left(\mathrm{~m}, \mathrm{CH}, \mathrm{PPh}_{3}\right), 145.8$ $\left(C_{\text {meta }}\right), 146.1\left(C_{\text {ipso }}\right)$. MS (MALDI-TOF): $m / z, 1034.0\left[\mathrm{M}-\mathrm{I}^{+}(\right.$calcd 1036.2), 899.0 [M - $\left.\mathrm{PPh}_{3}\right]^{+}$(calcd 901.0). Anal. Calcd for $\mathrm{C}_{48} \mathrm{H}_{48} \mathrm{I}_{2} \mathrm{~N}_{2} \mathrm{P}_{2-}$ Pt (1163.8): C, 49.54; H, 4.16; N, 2.41. Found C, 49.63; H, 4.23; N, 2.40 .

[PtI $\left.\left(\eta^{1}-\boldsymbol{C}-\mathrm{C}_{6} \mathbf{H}_{3}\left\{\mathbf{C H}_{2} \mathbf{N M e}_{2}\right\}_{2}-\mathbf{3 , 5}-\mathbf{P t I}-4\right)\left(\mathbf{P P h}_{3}\right)_{2}\right]$ 20. Method A: A solution of $19(0.30 \mathrm{~g}, 0.33 \mathrm{mmol})$ and $\left[\mathrm{Pt}\left(\mathrm{PPh}_{3}\right)_{4}\right](0.33 \mathrm{~g}, 0.41 \mathrm{mmol})$ in benzene $(30 \mathrm{~mL})$ was refluxed for $1 \mathrm{~h}$. Volatiles were then removed under reduced pressure. The crude product was isolated by repetitive precipitation of a $\mathrm{CH}_{2} \mathrm{Cl}_{2}$ solution with pentane and it was finally recrystallized from $\mathrm{CH}_{2} \mathrm{Cl}_{2}$ /benzene/pentane to afford $0.29 \mathrm{~g}$ of $\mathbf{2 0}$ (64\%).

Method B: A solution of $\mathbf{3 b}(50 \mathrm{mg}, 0.08 \mathrm{mmol})$ and $\left[\mathrm{Pt}\left(\mathrm{PPh}_{3}\right)_{4}\right]$ (97 mg, $0.08 \mathrm{mmol})$ in benzene $(30 \mathrm{~mL})$ was refluxed for $1 \mathrm{~h}$. Volatiles were then removed under reduced pressure and the crude product was isolated by repetitive precipitation of a $\mathrm{CH}_{2} \mathrm{Cl}_{2}$ solution with pentane, affording $100 \mathrm{mg}(94 \%)$ of $20 .{ }^{13} \mathrm{C}$ NMR $\left(75 \mathrm{MHz}, \mathrm{CD}_{2} \mathrm{Cl}_{2}\right) \delta=56.6$ $\left(\mathrm{NCH}_{3}\right), 77.3\left(\mathrm{CH}_{2}\right), 127.1,128.0,\left(\mathrm{t},{ }^{3} \mathrm{JC}_{\mathrm{PC}}=5.3 \mathrm{~Hz}, C_{\text {meta }}, \mathrm{PPh}_{3}\right), 130.5$ $\left(C_{\text {para }}, \mathrm{PPh}_{3}\right), 132.2\left(\mathrm{t},{ }^{3} J_{\mathrm{PC}}=28.1 \mathrm{~Hz}, C_{\text {ipso }}, \mathrm{PPh}_{3}\right), 132.4,135.6(\mathrm{t}$, $\left.{ }^{3} J_{\mathrm{PC}}=6.0 \mathrm{~Hz}, C_{\text {ortho }}, \mathrm{PPh}_{3}\right), 139.9,143.6$. MS (MALDI-TOF): $\mathrm{m} / \mathrm{z}$ $1356.4[\mathrm{M}]^{+}$(calcd 1358.1), $1228.6[\mathrm{M}-\mathrm{I}]^{+}$(calcd 1231.2). Anal. Calcd for $\mathrm{C}_{48} \mathrm{H}_{48} \mathrm{I}_{2} \mathrm{~N}_{2} \mathrm{P}_{2} \mathrm{Pt}_{2} \cdot \mathrm{C}_{6} \mathrm{H}_{6}$ (1437.0): C, 45.14; H, 3.79; N, 1.95 . Found: C, 44.77; H, 3.87; N, 1.96.

$\left[\operatorname{PdI}\left(\eta^{1}-C-\mathrm{C}_{6} \mathbf{H}_{3}\left\{\mathrm{CH}_{2} \mathrm{NMe}_{2}\right\}_{2}-3,5-\mathrm{PtI}-4\right)\left(\mathrm{PPh}_{3}\right)_{2}\right]$ 21. A solution of 3b $(110 \mathrm{mg}, 0.17 \mathrm{mmol})$ and $\left[\mathrm{Pd}\left(\mathrm{PPh}_{3}\right)_{4}\right](199 \mathrm{mg}, 0.17 \mathrm{mmol})$ in benzene $(30 \mathrm{~mL})$ was stirred at room temperature for $3 \mathrm{~h}$. The formed precipitated was collected and washed with pentane $(2 \times 15 \mathrm{~mL})$ to yield $160 \mathrm{mg}(73 \%)$ of $21 .{ }^{13} \mathrm{C} \mathrm{NMR}\left(75 \mathrm{MHz}, \mathrm{CDCl}_{3}\right) \delta=56.1$ 
$\left(\mathrm{NCH}_{3}\right), 76.7\left(\mathrm{CH}_{2}\right), 126.0,127.5,\left(\mathrm{t},{ }^{3} J_{\mathrm{PC}}=5.2 \mathrm{~Hz}, C_{\text {meta }}, \mathrm{PPh}_{3}\right), 129.7$ $\left(C_{\text {para }}, \mathrm{PPh}_{3}\right), 132.2\left(\mathrm{t},{ }^{3} J_{\mathrm{PC}}=22.9 \mathrm{~Hz}, C_{\mathrm{ipso}}, \mathrm{PPh}_{3}\right), 134.8\left(\mathrm{t},{ }^{3} J_{\mathrm{PC}}=6.1\right.$ $\left.\mathrm{Hz}, C_{\text {ortho }}, \mathrm{PPh}_{3}\right), 142.5,143.4,150.6$. Anal. Calcd for $\mathrm{C}_{48} \mathrm{H}_{48} \mathrm{I}_{2} \mathrm{~N}_{2} \mathrm{P}_{2-}$ PdPt ${ }^{\mathrm{C}_{6}} \mathrm{H}_{6}$ (1348.3): C, 48.10; H, 4.04; N, 2.08. Found: $\mathrm{C}, 48.50 ; \mathrm{H}$, $4.20 ; \mathrm{N}, 2.24$.

$\left[\mathbf{P t I}\left(\eta^{1}-\mathrm{C}-\mathrm{C}_{6} \mathrm{H}_{3}\left\{\mathrm{CH}_{2} \mathrm{NMe}_{2}\right\}_{2}-\mathbf{3 , 5}-\mathrm{PdI}-4\right)\left(\mathrm{PPh}_{3}\right)_{2}\right]$ 22. A solution of $2(60 \mathrm{mg}, 0.05 \mathrm{mmol})$ and $\left[\mathrm{Pd}_{2}(\mathrm{dba})_{3} \cdot \mathrm{CHCl}_{3}\right](24 \mathrm{mg}, 0.025 \mathrm{mmol})$ in benzene $(15 \mathrm{~mL})$ was refluxed for $15 \mathrm{~min}$. After this time the reaction mixture was cooled to room temperature and the formed precipitate was collected and washed with pentane $(2 \times 10 \mathrm{~mL})$. The resulting powder was then dissolved in acetone and an excess of $\mathrm{NaI}$ was added. The suspension was stirred overnight. After filtration of the reaction mixture, solvent was removed and the residue was dissolved in $\mathrm{CH}_{2-}$ $\mathrm{Cl}_{2}$. The organic phase was washed with water and brine and dried over $\mathrm{MgSO}_{4}$. After removal of the solvent, 22 was obtained as a yellow powder. Yield: $44 \mathrm{mg}(64 \%) .{ }^{13} \mathrm{C} \mathrm{NMR}\left(50 \mathrm{MHz}, \mathrm{CDCl}_{3}\right) \delta=54.7$ $\left(\mathrm{NCH}_{3}\right), 73.7\left(\mathrm{CH}_{2}\right), 125.9,127.5\left(\mathrm{t},{ }^{3} J_{\mathrm{PC}}=5.1 \mathrm{~Hz}, C_{\text {meta }}, \mathrm{PPh}_{3}\right), 130.0$ $\left(C_{\text {para }}, \mathrm{PPh}_{3}\right), 131.4\left(\mathrm{~m}, C_{\mathrm{ipso}}, \mathrm{PPh}_{3}\right), 132.0,135.0\left(\mathrm{t},{ }^{3} J_{\mathrm{PC}}=6.0 \mathrm{~Hz}\right.$, $\left.C_{\text {ortho }}, \mathrm{PPh}_{3}\right), 135.9,144.5$. MS (MALDI-TOF): $\mathrm{m} / \mathrm{z} 1140.7[\mathrm{M}-\mathrm{I}]^{+}$ (calcd 1142.1). Anal. Calcd for $\mathrm{C}_{48} \mathrm{H}_{48} \mathrm{I}_{2} \mathrm{~N}_{2} \mathrm{P}_{2} \mathrm{PdPt} \cdot \mathrm{CH}_{2} \mathrm{Cl}_{2}$ (1355.12): C, 43.43; H, 3.72; N, 2.07. Found: C, 43.50; H, 4.11; N, 1.70 .

$\left[\mathrm{PdI}\left(\eta^{1}-\mathrm{C}-\mathrm{C}_{6} \mathrm{H}_{3}\left\{\mathrm{CH}_{2} \mathrm{NMe}_{2}\right\}_{2}-3,5-\mathrm{PdI}-4\right)\left(\mathrm{PPh}_{3}\right)_{2}\right]$ 23. Solid $\left[\mathrm{Pd}_{2}-\right.$ $\left.(\mathrm{dba})_{3} \cdot \mathrm{CHCl}_{3}\right](0.27 \mathrm{~g}, 0.26 \mathrm{mmol})$ was added to a stirred solution of $1(0.2 \mathrm{~g}, 0.56 \mathrm{mmol})$ in toluene $(15 \mathrm{~mL})$ at $-80{ }^{\circ} \mathrm{C}$. The resulting solution was allowed to warm to room temperature and stirred overnight. The reaction mixture was filtered through Celite and the solvent was removed under reduced pressure. The solid residue was dissolved in wet acetone $(15 \mathrm{~mL}), \mathrm{AgBF}_{4}(0.21 \mathrm{~g}, 1.12 \mathrm{mmol})$ was added, and the suspension was stirred for $15 \mathrm{~min}$. After this time, the resulting cloudy solution was filtered through Celite, and the solvent was concentrated to ca. $5 \mathrm{~mL}$. Then $\mathrm{Et}_{2} \mathrm{O}$ was added $(20 \mathrm{~mL})$, which resulted in the formation of a precipitate that was collected and purified by repetitive washing with $\mathrm{Et}_{2} \mathrm{O}$. The solid was dissolved in $\mathrm{CH}_{2} \mathrm{Cl}_{2}$ $(20 \mathrm{~mL})$, an excess of LiI $(0.20 \mathrm{~g}, 1.50 \mathrm{mmol})$ was added, and the mixture was stirred for $3 \mathrm{~h}$. The suspension was subsequently filtered over Celite and the filtrate was washed with brine and water, dried over $\mathrm{MgSO}_{4}$, and concentrated. $\mathbf{4 b}$ was obtained as a yellow solid (yield $0.10 \mathrm{~g}, 39 \%)$

To a benzene solution of freshly prepared $4 \mathbf{b}(72 \mathrm{mg}, 0.13 \mathrm{mmol})$ at $0{ }^{\circ} \mathrm{C}$ was added $\mathrm{Pd}\left(\mathrm{PPh}_{3}\right)_{4}(75 \mathrm{mg}, 0.065 \mathrm{mmol})$. The reaction mixture was allowed to warm to room temperature and stirred during $1 \mathrm{~h}$. The formed precipitate was collected and washed with pentane $(2 \times 5 \mathrm{~mL})$ to yield $73 \mathrm{mg}(50 \%)$ of $23 .{ }^{13} \mathrm{C}$ NMR $\left(75 \mathrm{MHz}, \mathrm{CD}_{2} \mathrm{Cl}_{2}\right) \delta=55.1$ $\left(\mathrm{NCH}_{3}\right), 74.3\left(\mathrm{CH}_{2}\right), 127.1,128.2,\left(\mathrm{t},{ }^{3} J_{\mathrm{PC}}=4.9 \mathrm{~Hz}, C_{\text {meta }}, \mathrm{PPh}_{3}\right), 130.4$ $\left(C_{\text {para }}, \mathrm{PPh}_{3}\right), 132.9\left(\mathrm{t},{ }^{3} J_{\mathrm{PC}}=23.2 \mathrm{~Hz}, C_{\mathrm{ipso}}, \mathrm{PPh}_{3}\right), 135.4\left(\mathrm{t},{ }^{3} J_{\mathrm{PC}}=6.1\right.$ $\left.\mathrm{Hz}, C_{\text {ortho }}, \mathrm{PPh}_{3}\right), 145.7,153.5$, 154.1. Anal. Calcd for $\mathrm{C}_{48} \mathrm{H}_{48} \mathrm{I}_{2} \mathrm{~N}_{2} \mathrm{P}_{2}-$ $\mathrm{Pd}_{2} \cdot 2 \mathrm{C}_{6} \mathrm{H}_{6}$ (1337.7): C, 53.87; H, 4.52; N, 2.09. Found: C, 53.65; H, $4.15 ; \mathrm{N}, 2.51$.

[PtI(NCN-SiMe 3 -4)] 24. To a solution of $\mathbf{3 b}(0.55 \mathrm{~g}, 0.86 \mathrm{mmol})$ in THF $(40 \mathrm{~mL})$ was added dropwise $t$-BuLi $(1.10 \mathrm{~mL}, 1.5 \mathrm{M}$ in hexane, $1.63 \mathrm{mmol})$ at $-100{ }^{\circ} \mathrm{C}$. The solution was stirred for $5 \mathrm{~min}$ at low temperature and subsequently treated with $\mathrm{Me}_{3} \mathrm{SiCl}(0.45 \mathrm{~mL}, 3.5$ mmol). After being stirred for $15 \mathrm{~min}$, the reaction mixture was quenched with a saturated aqueous solution of $\mathrm{NH}_{4} \mathrm{Cl}(5 \mathrm{~mL})$. The resulting suspension was allowed to warm to room temperature and all volatiles were removed in vacuo. This crude product was dissolved in $\mathrm{CH}_{2} \mathrm{Cl}_{2}$, washed with brine, dried over $\mathrm{MgSO}_{4}$, and concentrated to afford $0.41 \mathrm{~g}$ of $24(75 \%) .{ }^{1} \mathrm{H}$ NMR $\left(200 \mathrm{MHz}, \mathrm{CDCl}_{3}\right): \delta=0.22$ (s, $\left.9 \mathrm{H}, \mathrm{SiMe}_{3}\right), 3.19\left(\mathrm{~s}, 12 \mathrm{H},{ }^{3} J_{\mathrm{PtH}}=38.8 \mathrm{~Hz}, \mathrm{~N}\left(\mathrm{CH}_{3}\right)_{2}\right), 4.03\left(\mathrm{~s}, 4 \mathrm{H},{ }^{3} J_{\mathrm{PtH}}\right.$ $\left.=45.8 \mathrm{~Hz}, \mathrm{CH}_{2}\right), 6.95(\mathrm{~s}, 2 \mathrm{H}, \mathrm{ArH}) \cdot{ }^{13} \mathrm{C} \mathrm{NMR}\left(75 \mathrm{MHz}, \mathrm{CDCl}_{3}\right): \delta$
$=-1.0\left(\mathrm{SiMe}_{3}\right), 56.3\left(\mathrm{~N}\left(\mathrm{CH}_{3}\right)_{2}\right), 76.9\left(\mathrm{CH}_{2}\right), 124.0\left(C_{\text {meta }}\right), 134.7\left(C_{\text {para }}\right)$, $143.1\left(C_{\text {ortho }}\right), 150.8\left(C_{\text {ipso }}\right)$. MS (MALDI-TOF): $m / z 460.7[\mathrm{M}-\mathrm{I}]^{+}$ (calcd 458.2). Anal. Calcd for $\mathrm{C}_{15} \mathrm{H}_{27} \mathrm{IN}_{2} \mathrm{SiPt}$ (585.5): C, 30.77; $\mathrm{H}$, 4.65; N, 4.78. Found: C, 30.61; H, 4.65; N, 4.72.

$[\mathbf{P t}(\mathbf{N C N})]_{n} \mathbf{2 5}$. To a solution of $\mathbf{3 b}(0.6 \mathrm{~g}, 1.0 \mathrm{mmol})$ in THF (20 $\mathrm{mL}$ ) was added dropwise $t$-BuLi (1.3 $\mathrm{mL}, 1.5 \mathrm{M}$ in hexane, $2.0 \mathrm{mmol})$ at $-100{ }^{\circ} \mathrm{C}$. Immediately, a precipitate was formed. The suspension was stirred for $5 \mathrm{~min}$ and subsequently allowed to slowly reach room temperature. The precipitate was collected, washed repeatedly with THF $(3 \times 20 \mathrm{~mL})$, and dried in vacuo to give $\mathbf{2 5}$ as an insoluble white solid $(0.23 \mathrm{~g})$.

[PtCl(NCN)] 26. A suspension of $\mathbf{2 5}(25 \mathrm{mg})$ in acetone $(5 \mathrm{~mL})$ was treated with gaseous $\mathrm{HCl}$. Immediately, the reaction mixture became homogeneous. All volatiles were removed in vacuo. Analysis of the residue gave identical NMR spectroscopic data $\left({ }^{1} \mathrm{H},{ }^{13} \mathrm{C}\right)$ as reported for 26. ${ }^{2 \mathrm{~b}}{ }^{1} \mathrm{H}$ NMR $\left(200 \mathrm{MHz}, \mathrm{CDCl}_{3}\right): \delta=3.08(\mathrm{~s}, 12 \mathrm{H}$, $\left.{ }^{3} J_{\mathrm{PtH}}=38.2 \mathrm{~Hz}, \mathrm{~N}\left(\mathrm{CH}_{3}\right)_{2}\right), 4.02\left(\mathrm{~s}, 4 \mathrm{H},{ }^{3} J_{\mathrm{PtH}}=45.6 \mathrm{~Hz}, \mathrm{CH}_{2}\right), 6.95$ $\left(\mathrm{d},{ }^{3} J_{\mathrm{HH}}=7.0 \mathrm{~Hz}, 2 \mathrm{H}, \mathrm{ArH}\right), 6.99\left(\mathrm{t},{ }^{3} J_{\mathrm{HH}}=7.0 \mathrm{~Hz}, 1 \mathrm{H}, \mathrm{ArH}\right)$.

[PtCl(NCN-D-4)] 28. A suspension of $25(25 \mathrm{mg})$ in $\mathrm{Ac}_{2} \mathrm{O}(2 \mathrm{~mL})$ and $\mathrm{D}_{2} \mathrm{O}(2 \mathrm{~mL})$ was refluxed for $5 \mathrm{~min}$ and the reaction mixture became homogeneous. All volatiles were removed in vacuo, the residue was dissolved in $\mathrm{CH}_{2} \mathrm{Cl}_{2}$, and the mixture was stirred in the presence of an excess of $\mathrm{NaI}$ for $1 \mathrm{~h} .{ }^{1} \mathrm{H} \mathrm{NMR}\left(300 \mathrm{MHz}, \mathrm{CDCl}_{3}\right)$ : $\delta=3.19(\mathrm{~s}$, $\left.12 \mathrm{H},{ }^{3} J_{\mathrm{PtH}}=37.5 \mathrm{~Hz}, \mathrm{~N}\left(\mathrm{CH}_{3}\right)_{2}\right), 4.03\left(\mathrm{~s}, 4 \mathrm{H},{ }^{3} J_{\mathrm{PtH}}=42.9 \mathrm{~Hz}, \mathrm{CH}_{2}\right)$, $6.82(\mathrm{~s}, 2 \mathrm{H}, \mathrm{ArH}){ }^{38}$

Crystal Structure Determinations. The crystal structures presented in this paper were solved with automated Patterson methods ${ }^{41}$ and refined with SHELXL- $97^{42}$ against $\mathrm{F}^{2}$ of all reflections. Structure drawings, calculations and checkings were performed with the PLATON package. ${ }^{43}$ Further details of the crystal structures are given in Table 4.

Crystallographic data (excluding structure factors) for the structures in this paper have been deposited with the Cambridge Crystallographic Data Centre as supplementary publications CCDC 175142 (2), 175143 (3a), 175144 (19), 175145 (20), and 175146 (24). Copies of the data can be obtained, free of charge, on application to CCDC, 12 Union Road, Cambridge CB2 1EZ, U.K. (fax +44 1223336033 or e-mail deposit@ccdc.cam.ac.uk).

Acknowledgment. G.R. thanks the European Commission for a Marie Curie TMR Grant (Contract HPMF-CT-199900236). This work was supported in part (M. L. and A.L.S.) by the Council for Chemical Sciences from the Dutch Organization for Scientific Research (CW-NWO).

Supporting Information Available: A complete list of the experimental procedure and analytical data for compound $\mathbf{1}$ (PDF), a listing of tables of atomic coordinates, bond lengths and angles, thermal parameters and relevant crystallographic data for compounds $\mathbf{2}, \mathbf{3 a}, \mathbf{1 9}, \mathbf{2 0}$, and $\mathbf{2 4}$ (CIF). This material is available free of charge via the Internet at http://pubs.acs.org.

\section{JA0177657}

(41) Beurskens, P. T.; Admiraal, G.; Beurskens, G.; Bosman, W. P.; GarciaGranda, S.; Gould, R. O.; Smits, J. M. M.; Smykalla, C. The DIRDIF97 Program System; Technical Report of the Crystallography Laboratory; University of Nijmegen: Nijmegen, The Netherlands, 1997.

(42) Sheldrick, G. M. SHELXL-97. Program for crystal structure refinement; University of Göttingen: Göttingen, Germany, 1997.

(43) Spek, A. L. PLATON. A multipurpose crystallographic tool; Utrecht University: Utrecht, The Netherlands, 2001 